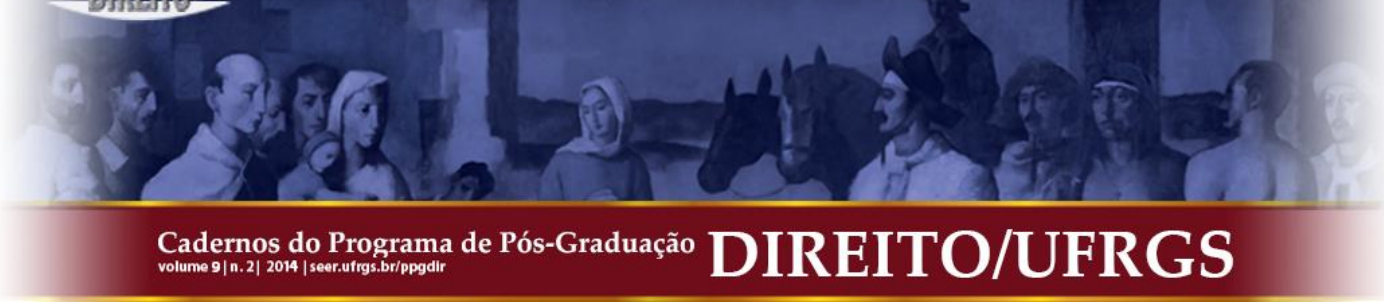

\title{
QUAL LIBERDADE DE IMPRENSA? A IMPRENSA CONCEBIDA COMO UM "FÓRUM ABERTO" OU COMO UM “CÃO DE GUARDA PRIVILEGIADO"*
}

\author{
WHICH FREEDOM OF THE PRESS? THE PRESS CONCEIVED AS AN 'OPEN FORUM' \\ OR A 'PRIVILEGED WATCHDOG'
}

Jens Elo Rytter ${ }^{* *}$

\begin{abstract}
RESUMO: $O$ artigo examina o significado histórico e contemporâneo de "liberdade de imprensa" no direito constitucional e nos direitos humanos. Existem duas concepções diferentes, a concepção restrita define a liberdade de imprensa como a liberdade de cada um para publicar sem censura prévia, a concepção mais ampla define-a como uma liberdade privilegiada da imprensa organizada para reunir e informar a respeito de informações de interesse público. Essas duas concepções têm respostas muito diferentes para a questão de saber se a imprensa deve desfrutar de algum privilégio de isenção da legislação ordinária, quando tal legislação restringe o limite da imprensa para informar o público a respeito de questões de interesse público.
\end{abstract}

PALAVRAS-CHAVE: Liberdade de imprensa; Liberdade de expressão; Regulação da mídia; Privilégios da imprensa.
ABSTRACT: The article surveys the historical and current meaning of "Freedom of the Press" in constitutional and human rights law. Two different conceptions exist, the narrow one defining freedom of the press as the freedom of every one to publish without prior restraint, the broader one defining it as a privileged freedom of the organised press to gather and report on information of public interest. These two conceptions have very different answers to the question of whether the press should enjoy some privilege to be exempt from ordinary legislation when such legislation restricts the access of the press to inform the public on matters of public interest.

SUMÁRIO: Introdução. 1. Os fundamentos históricos da liberdade de imprensa. 2. A imprensa como um "fórum aberto". 2.1. Liberdade de imprensa no Direito Constitucional estadunidense. 2.2. Vantagens da doutrina do "fórum aberto". 2.3. Objeções à doutrina do "fórum aberto". 3. A imprensa como um "cão de guarda privilegiado". 3.1. Liberdade de imprensa no Direito Constitucional alemão. 3.2. Liberdade de imprensa no âmbito da Convenção Europeia dos Direitos Humanos. 3.3 Vantagens da doutrina do "cão de guarda privilegiado". 3.4. Objeções à doutrina do "cão de guarda privilegiado". 4. Qual é "a imprensa" qualificada para privilégios de cão de guarda? 5. Em que medida o privilégio de imprensa cão de guarda deveria se estender? $5.1 \mathrm{Um}$ privilégio para receber informação. $5.2 \mathrm{Um}$ privilégio para buscar informações. 6. O Direito dinamarquês como exemplo do impacto e dos dilemas da doutrina do "cão de guarda privilegiado". 6.1. A proteção das fontes jornalísticas e de material. 6.2. Invasão de jornalistas para relatar manifestações. 6.3. Violação de jornalistas à lei no processo de investigação ("infiltração"). Considerações finais: qual o futuro da imprensa? Referências.

\section{INTRODUÇÃO}

Embora seja universalmente aceito que a liberdade de imprensa e de outros meios de comunicação é essencial para o funcionamento e manutenção de uma sociedade livre e democrática, não há um ponto assente a respeito do que "liberdade de imprensa" realmente signifique.

Será que "liberdade de imprensa" refere-se essencialmente à simples liberdade de cada um publicar informações e opiniões sem restrições, a liberdade de imprensa assim sendo essencialmente um mero produto da mais geral e abrangente liberdade de expressão? Ou será

\footnotetext{
* Publicação original: RYTTER, Jens Elo. Which Freedom of the Press? - The Press Conceived as an 'Open Forum' or a 'Privileged Watchdog'. Scandinavian Studies in Law, v. 55, pp. 181-210, 2010. Tradução de Gustavo Castagna Machado, com a autorização do autor.

** Professor de Direito Constitucional (Direitos Humanos), Faculdade de Direito da Universidade de Copenhague (Dinamarca).
} 


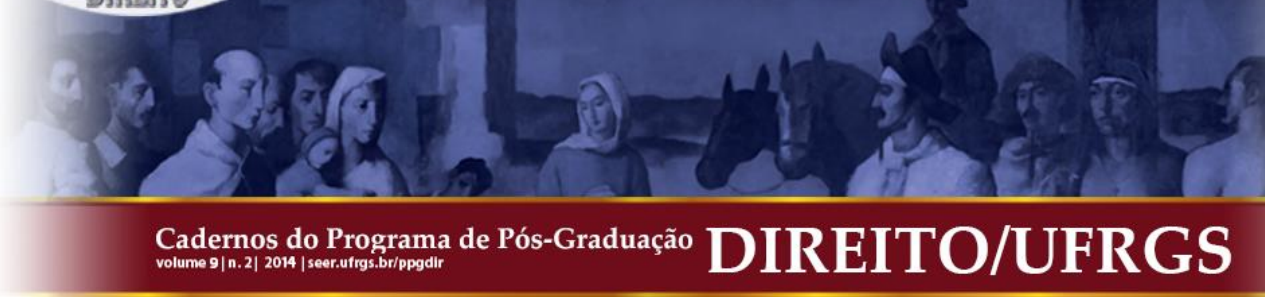

que "liberdade de imprensa" implica algo mais do que isso, a saber, a proteção da imprensa organizada que a permita cumprir de forma eficaz o seu papel estrutural de grupo de informação e controle em nome do público?

Essas duas concepções diferentes da noção de "liberdade de imprensa" têm diferentes implicações para a proteção jurídica da imprensa. Notavelmente, é provável que elas difiram na resposta à questão de haver ou não algum privilégio especial da imprensa que deva ser isento das exigências da legislação ordinária, quando essas exigências limitam o acesso da imprensa ao recolhimento de informação relevante que é inerente à garantia da "liberdade da imprensa".

Antes de discutir as diferentes concepções de liberdade de imprensa e suas implicações jurídicas no que diz respeito à aceitação de privilégios/imunidades especiais de imprensa é útil dar uma breve olhada nos fundamentos históricos da liberdade de imprensa.

\section{OS FUNDAMENTOS HISTÓRICOS DA LIBERDADE DE IMPRENSA}

É ponto assente que a liberdade de imprensa está intimamente conectada com o direito de liberdade de expressão; ambos originam-se do reconhecimento de que um debate livre e aberto é benéfico para a sociedade, bem como para o indivíduo. Historicamente, no entanto, o reconhecimento jurídico de uma liberdade de imprensa - no sentido de liberdade de censura na publicação - precedeu o reconhecimento da liberdade de expressão em geral. Embora isso possa, acima de tudo, ser devido ao fato de que os governantes eram os mais preocupados com a censura de impressos, ao reconhecer seu potencial de influenciar a opinião pública e atiçar a agitação pública, isso não demonstra que a liberdade de imprensa sempre mereceu especial atenção.

Desde a invenção da imprensa, no final do século XV, foi reconhecido que a imprensa oferece uma maneira eficaz de disseminar opiniões e informações e, consequentemente, os governantes esforçaram-se para restringir e censurar sua utilização. Na Inglaterra, também, a censura floresceu ao longo dos séculos XVI e XVII. ${ }^{1}$ No entanto, até o final do século XVII, ela foi finalmente abolida por inspiração, nada menos, do famoso discurso de Milton ao Parlamento inglês em 1644, que criticava o sistema inglês de censura e defendia a liberdade

\footnotetext{
${ }^{1}$ Cf. LANGE, David. The Speech and Press Clauses. U.C.L.A. Law Review, v. 23, pp. 77-119, 1975.
} 


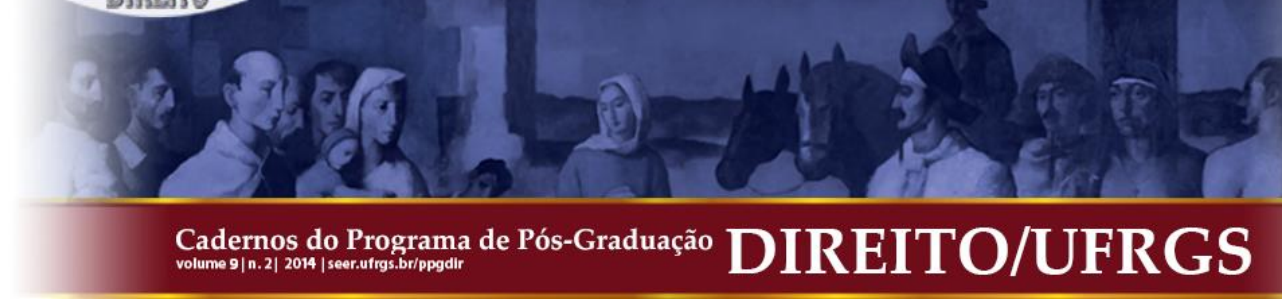

de imprimir sem licença como pré-requisito da vitória da verdade sobre a mentira e abusos. ${ }^{2}$ Assim, em meados do século XVIII, Blackstone poderia com autoridade descrever a liberdade de imprensa - a proibição de censura prévia na publicação - como um princípio estabelecido do direito comum inglês, considerado essencial para a natureza de um Estado livre. ${ }^{3}$

Essa concepção original inglesa de liberdade de imprensa, como a liberdade de cada um a imprimir e publicar sem censura prévia, foi influente quando nas décadas seguintes outros Estados europeus incluíram, de uma forma ou de outra, a liberdade de imprensa dentre suas garantias constitucionais.

A primeira proteção constitucional da liberdade de imprensa seria encontrada na Lei de Liberdade de Imprensa (Tryckfrihetsförordningen) sueca de 1766, que estipula, dentre outros, um direito de "cada cidadão sueco" publicar matéria escrita sem restrições prévias, Art. 1; e, a respeito de ofensa à liberdade de imprensa, estímulos foram dados para se manter em mente que a "liberdade de imprensa é fundamental para uma sociedade livre", Art. 4. Na Declaração Francesa dos Direitos do Homem e do Cidadão, de 1789, a liberdade de expressão é louvada como um dos direitos mais preciosos, o que implica um direito a todos a falar, escrever e imprimir, Art. 11. A Constituição norueguesa de 1814 dispõe no mesmo artigo da liberdade de imprensa - ou seja, a liberdade de impressão -, bem como da liberdade de expressão, Art. 100. A Constituição belga de 1831 dispõe, em separado, da liberdade de expressão e de uma imprensa livre, sem censura, Art. 14 e 18, respectivamente. A Constituição alemã de 1849 dispõe da liberdade de expressão em geral, incluindo a liberdade de publicar, mas também proíbe especificamente a suspensão da liberdade de imprensa por meio de qualquer tipo de medida preventiva, Art. 143. A Constituição dinamarquesa de 1849 não se refere explicitamente à imprensa, proclamando simplesmente que "qualquer pessoa deverá ter a liberdade para publicizar suas ideias pela impressão, escrita ou expressão" e proíbe qualquer tipo de censura ou outra limitação prévia à publicação (a censura estava até então em pleno funcionamento).

Na Constituição dos Estados Unidos da América, a Primeira Emenda, aprovada em 1791, prevê, dentre outros, que “o Congresso não fará lei que restrinja [...] a liberdade de expressão ou de imprensa". Essa disposição constitucional a respeito da liberdade de

\footnotetext{
${ }^{2}$ MILTON, John. Areopagitica. Reprinted. Cambridge: Cambridge University Press, 1918.

${ }^{3}$ BLACKSTONE, William. Commentaries on the Laws of England. Chicago: Callaghan and Company, 1899 (1765-69), ver pp. 150-153.
} 


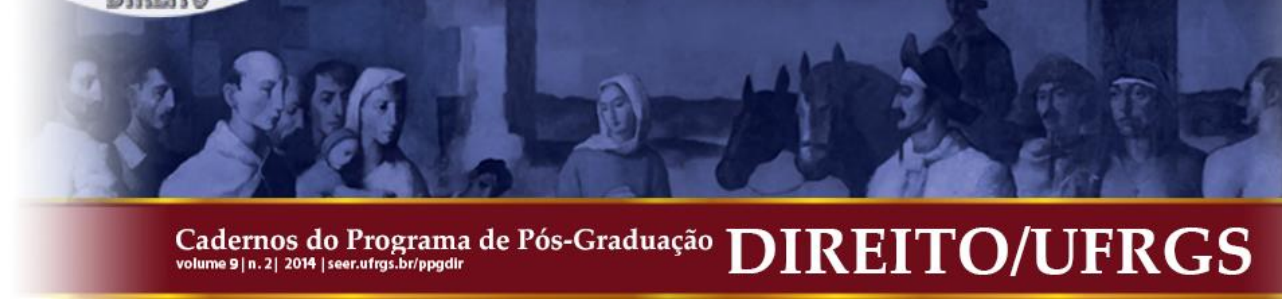

expressão e de imprensa alcançou status quase mítico como uma liberdade que contém a essência e o espírito da sociedade estadunidense. No entanto, o significado original do dispositivo de imprensa foi e continua a ser controverso.

Nos debates da época, parece que as noções de liberdade de expressão e liberdade de imprensa foram frequentemente usadas como sinônimos, a liberdade de imprensa referindo-se à liberdade de expressão por meio da impressão. ${ }^{4}$ Assim, com base nas raízes históricas da liberdade de imprensa e no fato de que o pensamento jurídico estadunidense sempre esteve muito baseado no direito comum inglês, um primeiro impulso seria afirmar que a referência específica à liberdade de imprensa ao lado de liberdade de expressão da Primeira Emenda simplesmente teve a intenção de destacar que a liberdade de expressão também implicava para todos uma liberdade de publicar material impresso, reconhecendo a importância crucial para um Estado livre desse veículo de informação e de opinião e o registro histórico de restrições a publicação. ${ }^{5}$ Essa leitura da Primeira Emenda se encaixaria muito bem também com outros dispositivos europeus a respeito de imprensa livre da época.

No entanto, também se pode encontrar suporte histórico para uma visão mais estrutural do dispositivo que trata da imprensa na Primeira Emenda. Em primeiro lugar, um fundo (background) importante para sua adoção foi o papel crucial desempenhado pela imprensa como um veículo para a formação da opinião pública na luta dos colonizadores norteamericanos pela independência. Em segundo lugar, a Constituição dos Estados Unidos fundou a primeira verdadeira democracia dos tempos modernos, onde todo o poder do Estado emana do povo, e onde a imprensa foi, portanto, considerada não apenas como um veículo de informação, mas também como controle do público no exercício do poder público.

Várias das constituições estaduais que antecederam a Constituição da União garantiam a liberdade de imprensa. Enquanto algumas aparentemente consideraram a imprensa apenas como um importante veículo de expressão, outras ressaltaram também a importância constitucional crucial de uma imprensa livre. Um exemplo do primeiro tipo é encontrado na Constituição da Pensilvânia (1776), Art. XII: “[O] povo tem direito à liberdade de expressão e de escrever e publicar os seus sentimentos, por isso a liberdade de imprensa não deve ser limitada”. Exemplos desse último tipo são encontrados na Constituição da Virgínia (1776),

\footnotetext{
${ }^{4}$ Ver NIMMER, Melville B. Introduction - Is Freedom of the Press a Redundancy: What does it add to Freedom of Speech? Hastings Law Journal, v. 26, pp. 639-658, 1975.

${ }^{5}$ Cf. e.g. LANGE, David. The Speech and Press Clauses. U.C.L.A. Law Review, v. 23, pp. 77-119, 1975.
} 


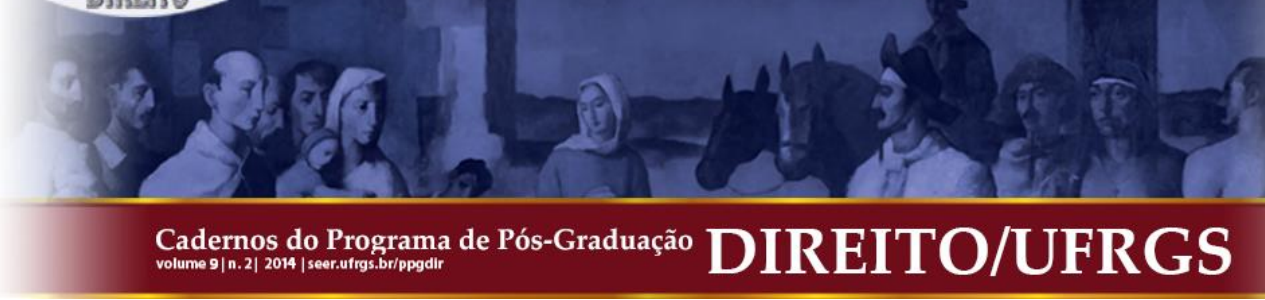

Art. 12 "[A] liberdade de imprensa é um dos grandes baluartes da liberdade, e jamais pode ser limitada, exceto por governos despóticos"; Constituição de Massachusetts (1780), Art. XVI: "A liberdade de imprensa é essencial para a segurança da liberdade de um Estado, que não deve, pois, ser limitada nesta comunidade (commonwealth)".

James Madison, o autor da Primeira Emenda, referindo-se a essas características históricas e constitucionais deixa claro que a cláusula de imprensa livre na Primeira Emenda tem um significado mais amplo do que a liberdade de imprensa na Grã-Bretanha. Em sua visão, a imprensa deve gozar de forte proteção contra qualquer restrição ou penalidade que iniba sua função - indispensável para uma sociedade livre e democrática - como informante do povo autogovernado e um controlador do governo em nome do povo. ${ }^{6}$ Madison afirma, dentre outras coisas:

\begin{abstract}
Em todos os estados, provavelmente, na União, a imprensa tem exercido uma liberdade de examinar os méritos e as medidas dos homens públicos [...]. E pode a sabedoria dessa política (policy) ser posta em dúvida por qualquer um que reflita, que apenas à imprensa, acidentada como ela é com abusos, o mundo está em dívida por todos os triunfos que foram conquistados pela razão e pela humanidade sobre o erro e a opressão; que reflita, que à mesma fonte benigna os Estados Unidos devem muitas das luzes que o conduziu ao posto de uma nação livre e independente, e que melhorou seu sistema político de uma forma tão auspiciosa para a sua felicidade. ${ }^{7}$
\end{abstract}

O contexto histórico do dispositivo que trata da imprensa livre na Primeira Emenda, assim, pode ser visto como sugestivo de um papel estrutural da imprensa no quadro constitucional, alcançando mais do que as funções de um mero veículo de informações que deve permanecer sem restrições, a ponto de se tornar uma espécie de "quarto poder" institucional, fornecendo uma verificação adicional sobre o poder público por um organismo especializado organizado. Se assim for, essa visão estava até certo ponto baseada mais no que a imprensa poderia tornar-se do que no que realmente era; no momento em que a Primeira Emenda foi redigida, uma imprensa organizada no sentido moderno realmente não existia; os jornais ainda eram pequenos, dispersos e com poucos leitores. ${ }^{8}$ Não foi até meados do século XIX que (alguns) jornais surgiram como poderosa mídia de massa no sentido moderno. ${ }^{9}$

\footnotetext{
6 Ver MADISON, James. The Virginia Report of 1799. Reprinted. In: EPPS, Garrett (Ed.). The First Amendment. Freedom of the press: its constitutional history and the contemporary debate. Amherst: Prometheus Books, 2008, pp. 78-81.

${ }^{7}$ MADISON, James. Op. cit. [nota 6], pp. 79-80.

${ }^{8}$ Cf. LEWIS, Anthony. Freedom for the Thought that we Hate (2007). Excerpt reprinted. In: KOHLER, D.; LEVINE, L. Media and the Law. Newark: LexisNexis, 2009, pp. 4-5; Ver também a concepção de 1830 de Alexis de Tocqueville em Democracy in America. Chapter XI (1840). Reprinted. In: EPPS, Garrett (Ed.).
} 


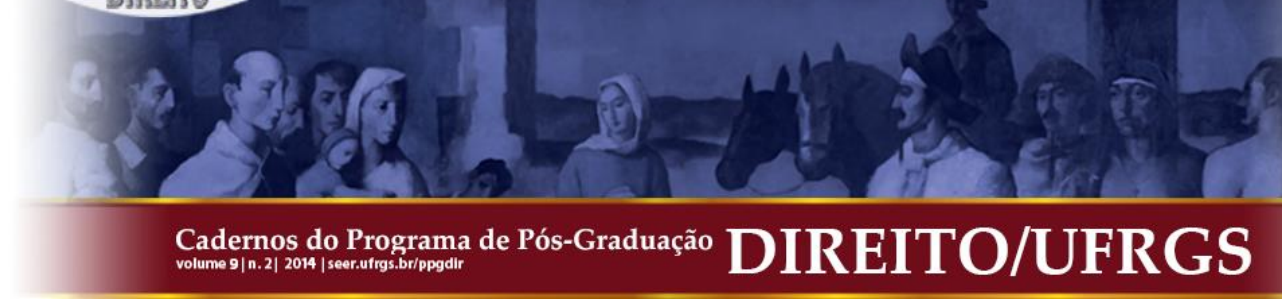

Em suma, a partir de uma perspectiva originalista, a concepção mais óbvia da liberdade de imprensa seria a do "fórum aberto" - uma liberdade para todos de impressão e publicação sem restrição. No entanto, a história estadunidense da Primeira Emenda, em particular, oferece também, pelo menos, algumas indicações rudimentares de uma visão mais abrangente da liberdade de imprensa - uma liberdade que protege uma instituição com a destacada função de "cão de guarda" sob uma constituição democrática de informar o público e responsabilizar as pessoas no poder em nome do público. Uma escolha entre essas marcadamente diferentes concepções de liberdade de imprensa se tornou, assim, disponível para a posteridade. Como veremos, sistemas jurídicos diferentes - seja em razão de diferenças de tradição jurídica, filosofia política ou ambos - optaram por diferentes concepções do que a liberdade de imprensa significa; e a escolha realizada teve implicações significativas para a proteção jurídica e os privilégios de imprensa.

\section{A IMPRENSA COMO UM "FÓRUM ABERTO"}

A concepção restrita e originalista de liberdade de imprensa é que ela garante, no essencial, a liberdade de todos para publicar opiniões e informações sem restrição pública.

\subsection{Liberdade de Imprensa no Direito Constitucional Estadunidense}

O sentido e alcance da garantia da Primeira Emenda de que "O Congresso não fará lei que restrinja [...] a liberdade de imprensa" foi e continua a ser controverso. No entanto, a concepção "fórum aberto" da liberdade de imprensa é predominante no direito constitucional estadunidense. A Suprema Corte pode ter repetidamente confirmado o ponto de vista de Madison de uma especialmente forte proteção da imprensa em termos gerais, considerando que enquanto a liberdade de censura prévia sobre a publicação permanece seu núcleo, esse não esgota a liberdade contida na liberdade de imprensa. ${ }^{10}$ A Corte também elogiou repetidamente em termos gerais o papel fundamental da liberdade de expressão e da liberdade

\footnotetext{
The First Amendment. Freedom of the press: its constitutional history and the contemporary debate. Amherst: Prometheus Books, 2008, pp. 87-95.

${ }^{9}$ Cf. ANDERSON, David A. The Origins of the Press Clause. U.C.L.A. Law Review, v. 30, 455-541, 1983; BARBER, Phil. A Brief History of Newspapers. Disponível em: < www.historicpages.com/nprhist.htm >. Acesso em 2010.

${ }^{10}$ Ver, em especial, Near vs. Minnesota, 283 U.S. 697 (1931), nas pp. 713-718; Grosjean vs. American Press Co. 297 U.S. 233 (1936), nas pp. 248-250; Lovell vs. City of Griffin, 303 U.S. 444, nas pp. 451 (1938).
} 


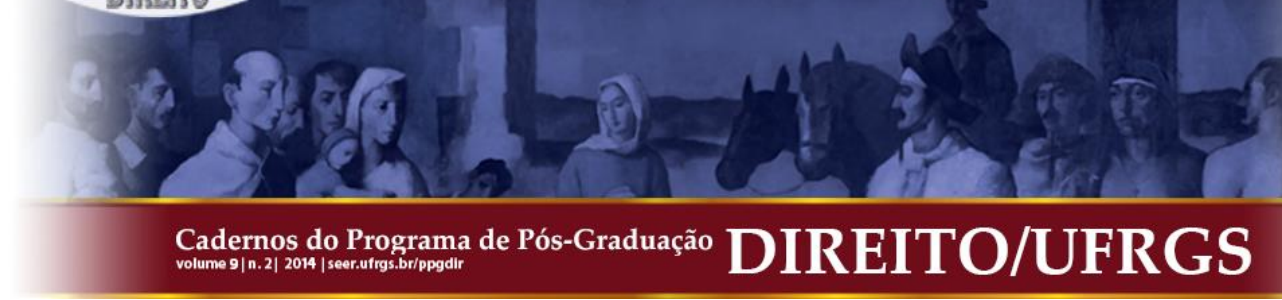

de imprensa para o funcionamento de um Estado democrático. ${ }^{11}$ No entanto, a Suprema Corte não está disposta a concluir que a Primeira Emenda implica uma proteção constitucional especial da imprensa organizada.

De acordo com a Suprema Corte, resulta da doutrina tradicional e do contexto do dispositivo que trata da imprensa livre que a liberdade de imprensa da Primeira Emenda é uma liberdade de publicação pertencentes a todas as pessoas, sem proteção especial a ser dada para a imprensa estabelecida (established), profissional: "A liberdade de imprensa não se limita aos jornais e periódicos [...]. A imprensa, em sua conotação histórica, abrange todo o tipo de publicação que proporciona um veículo de informação e de opinião." 12

[L]iberdade de imprensa é o direito do panfletário solitário que usa papel carbono ou um mimeógrafo assim como da grande editora metropolitana que utiliza os métodos mais recentes de fotocomposição [...]. A liberdade de imprensa é um "direito pessoal fundamental", 13

Quanto ao aspecto material da liberdade de imprensa, a Suprema Corte reconhece que a liberdade de publicação irrestrita implica também alguma proteção ao acesso para coletar informações, uma vez que sem esse acesso não teria realmente muito a ser publicado: "Sem alguma proteção para buscar notícias, a liberdade de imprensa poderia ser eviscerada [...]. [...] os jornalistas permanecem livres para buscar notícias de qualquer fonte por meios permitidos pelo Direito."14

Isso implica claramente que a Suprema Corte encontraria proteção na cláusula imprensa livre contra as medidas destinadas especificamente a restringir a liberdade de imprensa para coletar informações. No entanto, a Suprema Corte tem estado menos disposta a aceitar que a imprensa deve estar isenta de leis de aplicação geral, mesmo que tais leis possam incidentalmente restringir a coleta de informações por parte da imprensa.

Sem surpresa, a Suprema Corte rejeitou uma proteção absoluta, ${ }^{15}$ de fornecer imunidade para a imprensa de todas as leis gerais que incidentalmente invadam o seu acesso livre para reunir informações: “[O] direito de falar e publicar não carrega consigo o direito irrestrito de

\footnotetext{
${ }^{11}$ Ver New York Times Co. vs. United States, 376 U.S. 254 (1964), na p. 269-271, com outras referências à jurisprudência.

${ }^{12}$ Lovell vs. City of Griffin, 303 U.S. 444 (1938), na p. 452.

${ }^{13}$ Branzburg vs. Hayes, 408 U.S. 665 (1972), White (Voto), na p. 704. Ver também Blackmun (vencido) em Cohen vs. Cowles Media Co., 501 U.S. 663 (1991), na p. 673.

${ }^{14}$ Branzburg vs. Hayes, 408 U.S. 665 (1972), na p. 681.

15 No entanto, ver em favor de uma interpretação da Primeira Emenda fornecendo proteção absoluta para a imprensa, Justice Douglas (vencido) em Branzburg vs. Hayes, 408 U.S. 665 (1972), nas pp. 713-714.
} 


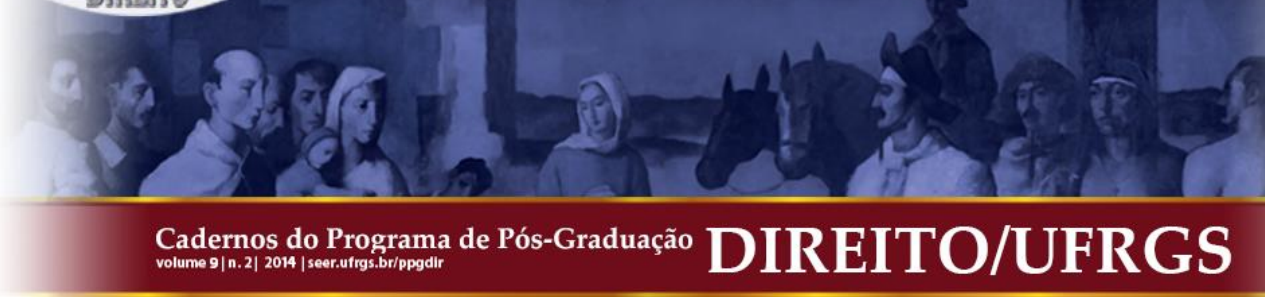

reunir informação."16 "É claro que a Primeira Emenda não invalida cada ônus incidental da imprensa que possa resultar da aplicação das leis civis ou criminais de aplicação geral." 17

Mais importante, a Suprema Corte - ou melhor, a maioria da Corte - tem afirmado repetidamente que a imprensa e suas atividades de coleta de informações devem operar dentro dos mesmos limites que se aplicam a qualquer outro cidadão. Isso já foi escrito de forma bastante clara em uma decisão de 1937: “O editor de um jornal não tem imunidade especial da aplicação de leis gerais. Ele não tem qualquer privilégio especial para invadir os direitos e liberdades dos outros." 18

Essa rejeição geral de qualquer privilégio constitucional para a imprensa que a isente de leis gerais foi reafirmada pela maioria da Corte em termos inequívocos, em uma decisão de 1991:

É [...] indiscutível que "o editor de um jornal não tem imunidade especial da aplicação de leis gerais". [...] Assim, a aplicação de tais leis gerais contra a imprensa não está sujeita a um escrutínio mais rigoroso (stricter scrutiny) do que seria aplicado contra outras pessoas ou organizações. ${ }^{19}$

Consequentemente, sob a existente doutrina da imprensa livre, a imprensa goza de nenhum privilégio testemunhal [sigilo da fonte] para proteger as fontes jornalísticas sob a Primeira Emenda (mas a maioria dos estados já previu tal privilégio na sua legislação). ${ }^{20}$ Inversamente, a promessa de um jornalista da confidencialidade é tão vinculante para ele como seria para qualquer pessoa. ${ }^{21}$ Também não está a imprensa imune de sanções quando ultrapassa a propriedade privada, a fim de informar sobre eventos de interesse público. ${ }^{22}$ Claramente, qualquer privilégio de imprensa para violações autônomas do Direito no processo de busca de informações está a fortiori excluído. Como a Suprema Corte (maioria) afirmou

\footnotetext{
${ }^{16}$ Zemel vs. Rusk, 381 U.S. 1 (1965), na p. 17.

${ }^{17}$ Branzburg vs. Hayes, 408 U.S. 665 (1972), na p. 682.

18 Associated Press vs. NLRB, 301 U.S. 103 (1937), nas pp. 132-133.

${ }^{19}$ Cohen vs. Cowles Media Co., 501 U.S. 663 (1991), White (voto), nas pp. 669-670 - decidido por quatro votos a cinco.

${ }^{20}$ Branzburg vs. Hayes, 408 U.S. 665 (1972) - decidido por quatro votos a cinco (com o Justice Powell, embora ao lado do voto vencedor, mantendo uma porta aberta para privilégios limitados em circunstâncias diferentes). Essa posição foi confirmada por obiter dictum em Cohen vs. Cowles Media Co., 501 U.S. 663 (1991) - mais uma vez decidido por quatro votos a cinco.

${ }^{21}$ Cohen v. Cowles Media Co., 501 U.S. 663 (1991) decidido por quatro votos a cinco; reconhecendo que uma ação de responsabilidade civil poderia ser movida contra um jornalista que havia publicado a identidade de sua fonte, apesar de sua promessa de não fazê-lo.

${ }^{22}$ Ver na jurisprudência estadual Stahl vs. State, 665 P. 2d 839 (Okla. Ct. Crim. App. 1983) - relativo a uma manifestação contra energia nuclear em propriedade de acesso restrito, e a imprensa invadiu o local para cobrir a manifestação.
} 


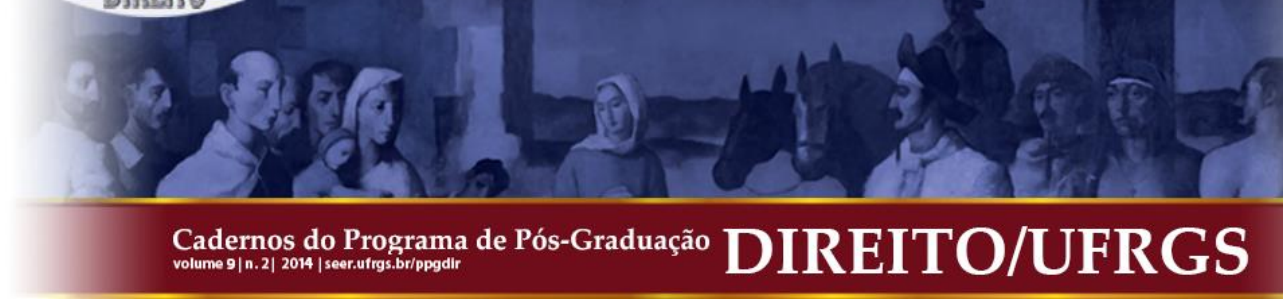

em Cohen vs. Cowles Media Co., de 1991: “[A]s informações verdadeiras buscadas para publicação devem ter sido juridicamente adquiridas. A imprensa não pode impunimente arrombar e entrar em um escritório ou habitação para obter notícias; [etc.] (.....”23

Em suma, de acordo com a visão predominante no direito constitucional estadunidense, não existe tal coisa como um privilégio de imprensa que isente da lei geral. A liberdade de imprensa existe no quadro da lei geral e os ônus incidentes sobre a capacidade da imprensa para coletar informações, decorrentes de leis de aplicação geral, não são considerados como limitações à liberdade de imprensa.

\subsection{Vantagens da Doutrina do "Fórum Aberto"}

Além de sua base sólida nos fundamentos históricos da liberdade de imprensa, a vantagem óbvia da concepção "fórum aberto" é que ela oferece uma doutrina bastante clara da liberdade de imprensa. É fácil de entender e fácil de aplicar. Assim como a liberdade de expressão que se aplica a todos os envolvidos na publicação e, portanto, não é necessário decidir quem se qualifica e quem não se qualifica para o rótulo de imprensa. Ela protege a publicação de censura prévia e, em certa medida, também de sanções com base no conteúdo publicado. Ela não confere à "imprensa organizada" quaisquer privilégios especiais ou imunidades; membros da imprensa organizada, como qualquer outro cidadão, devem agir no âmbito da lei geral. Assim, a concepção "fórum aberto" da liberdade de imprensa evita problemas de definição da "imprensa" e de delimitação de possíveis privilégios da imprensa. ${ }^{24}$

\subsection{Objeções à Doutrina do "Fórum Aberto"}

Uma objeção jurídica formal é que tal concepção restrita da liberdade de imprensa, essencialmente, torna redundante uma cláusula específica a respeito da liberdade de imprensa, uma vez que a liberdade de todos para publicar já é inerente (pelo menos na visão de hoje) à liberdade de expressão. ${ }^{25}$

\footnotetext{
${ }^{23}$ Cohen vs. Cowles Media Co., 501 U.S. 663 (1991), White (Voto), na p. 669 - decidido por cinco votos a quatro.

${ }^{24}$ Cf. a rejeição da maioria ao privilégio testemunhal da imprensa [sigilo de fonte] em Branzburg vs. Hayes, 408 U.S. 665 (1972), nas pp. 702-704.

${ }^{25}$ Ver e.g. ANDERSON, David A. Freedom of the Press. Texas Law Review, v. 80, i. 3, pp. 429-530, 2002; HORWITZ, Paul. Or of the [blog]. Excerpt reprinted. In: EPPS, Garrett (Ed.). The First Amendment. Freedom of the press: its constitutional history and the contemporary debate. Amherst: Prometheus Books, 2008, pp. 327; BARENDT, Eric. Freedom of Speech. $2^{\text {nd }}$ ed. Oxford: Oxford University press, 2008, p. 420.
} 


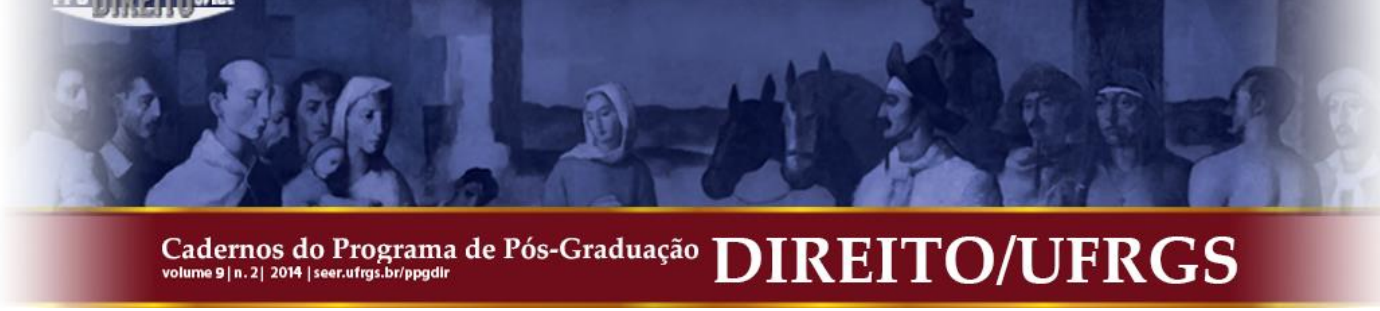

A objeção mais fundamental, no entanto, é que a concepção "fórum aberto" da liberdade de imprensa às vezes produz resultados que não são facilmente aceitáveis. Embora considerem a liberdade de imprensa como, em primeiro lugar, um direito fundamental do indivíduo, mesmo os apoiantes da doutrina "fórum aberto" reconhecem a importância crucial para a democracia de uma imprensa independente que reúna e divulgue informações ao público. A liberdade de imprensa não é, portanto, apenas um direito individual; também é fundamental para melhorar o direito do público de ser informado e permitir ao público que, por meio da imprensa, controle o governo e outras entidades do poder. ${ }^{26}$ A esse respeito, a liberdade de imprensa se difere de muitas outras liberdades que protegem principalmente interesses individuais.

Por exemplo, a liberdade de religião serve predominantemente, se não exclusivamente, ao interesse do indivíduo ou minoria religiosa que o reivindique e, portanto, não preponderará fácil sobre o interesse público da imposição a todos, sem distinção, da legislação ordinária que incidentalmente crie um ônus a alguma religião. Presumivelmente, isso é uma razão importante por que isenções religiosas da legislação geral parecem ser geralmente rejeitadas, não apenas nos Estados Unidos. ${ }^{27}$

É por isso que os privilégios de imprensa - mesmo vistos a partir da restrita concepção de liberdade de imprensa de "fórum aberto" - não são tão facilmente eliminados. O interesse constitucional e democrático inconteste de o público ser informado e de o poder público ser verificado terá peso, mesmo quando as restrições à imprensa são apenas uma consequência incidental de leis de aplicação geral. O Justice Souter da Suprema Corte dos Estados Unidos distanciando-se da rejeição da maioria de qualquer imunidade da imprensa a leis gerais e sendo acompanhado por três outros juízes - colocou desta forma:

[N]ão há nada de mágico a respeito das leis de aplicabilidade geral [...] pois tais leis podem restringir os direitos da Primeira Emenda tão eficazmente como aquelas direcionadas especificamente à própria expressão. [...] A liberdade de imprensa está, em última análise, fundada no valor de melhorar tal discurso [público] pelo bem de

\footnotetext{
${ }^{26}$ Ver também BARENDT, Eric. Freedom of Speech. $2^{\text {nd }}$ ed. Oxford: Oxford University press, 2008, p. 422, que muito exatamente descreve-o como se a liberdade de imprensa fosse "um direito instrumental, em vez de um direito básico ou fundamental".

${ }^{27}$ O leading case da Suprema Corte dos EUA é Employment Division vs. Smith, 402 U.S. 872 (1990), quando a maioria (6-3) categoricamente rejeitou uma reivindicação constitucional por uma tribo indígena de isenção da legislação penal estadual que proíbe a utilização de euforizantes, uma reivindicação baseada no fato de que a droga Peyote durante séculos foi utilizada pela tribo em cerimônias religiosas. O Tribunal de Estrasburgo parece seguir em grande medida a mesma linha. Ver, por exemplo, a declaração em Refah Partisi (Partido do BemEstar) e outros c. Turquia, julgamento da Grande Câmara de 13 fev. 2003, Ap. nº. 41340/98 et al, parágrafo 92, relativo ao dever geral, mesmo para Sikhs que usam turbantes, de usar um capacete ao dirigir uma moto.
} 


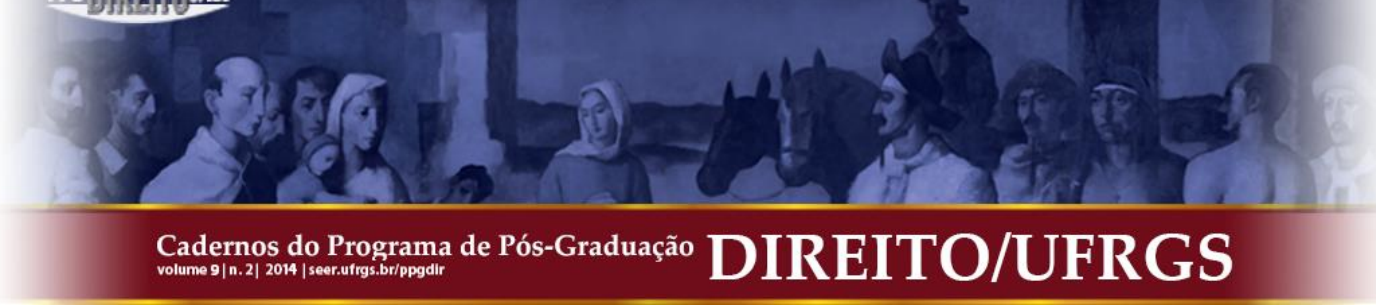

uma cidadania melhor informada e, portanto, mais prudentemente autogovernada [...]. A Primeira Emenda vai além da proteção da imprensa e da autoexpressão de indivíduos para proibir os governos de limitar o estoque de informações dos quais membros do público podem obter [informações] [...]. É o direito do público, e não o direito da [imprensa] que é fundamental. ${ }^{28}$

Um exemplo claro do dilema é a rejeição da Suprema Corte dos Estados Unidos de um privilégio testemunhal [sigilo de fonte] de repórteres para proteger suas fontes de informação - um privilégio clássico da imprensa - em Branzburg vs. Hayes. ${ }^{29}$ Enquanto tal rejeição é apenas uma consequência lógica da concepção "fórum aberto", é difícil negar que ao categoricamente rejeitar tal privilégio à imprensa dificulta-se a sua capacidade de reunir informações críticas de forma eficaz. Assim, pode-se detectar certo desconforto, hesitação e até mesmo reserva na opinião majoritária do Justice White, ao rejeitar um privilégio testemunhal [sigilo de fonte] para a imprensa. Pela mesma razão, a minoria do Tribunal, liderada pelo Justice Stewart, foi extraordinariamente dura em sua crítica, ao afirmar que a rejeição de um privilégio testemunhal [sigilo de fonte] deixaria a imprensa incapaz de realizar suas funções públicas de forma eficaz:

O ponto de vista infeliz da Corte da Primeira Emenda reflete uma insensibilidade perturbadora ao papel crítico da imprensa independente em nossa sociedade. [...] [E]ssa decisão [vai] prejudicar o desempenho das funções constitucionalmente protegidas da imprensa [...]. A imprensa "tem sido um poderoso catalisador para despertar o interesse público em assuntos governamentais, expondo a corrupção entre agentes e servidores públicos e, geralmente, informando os cidadãos de eventos e ocorrências públicas" [...]. Na medida em que as concentrações de poder públicas e privadas aumentam de tamanho e as pressões por conformidade necessariamente se elevam, existe, obviamente, uma necessidade contínua que uma imprensa independente divulgue uma variedade robusta de informação e de opinião por meio de reportagem, investigação e crítica, se quisermos preservar a nossa tradição constitucional de maximizar a liberdade de escolha ao encorajar a diversidade de expressão. ${ }^{30}$

A essência dessa crítica é que ao não permitir que alguma posição preferida da imprensa seja, por vezes, isenta das leis de aplicabilidade geral, deixará a imprensa (organizada) ineficaz no cumprimento de sua função constitucional de reunir e difundir informações relevantes ao público. Esse argumento, no entanto, aponta na direção de uma visão totalmente diferente do papel da imprensa e de sua liberdade constitucional. Assim, Justice Stewart, apoiado por outros, tem afirmado que a Primeira Emenda garante - e também foi feita

\footnotetext{
${ }^{28}$ Justice Souter (vencido), Cohen vs. Cowles Media Co., 501 U.S. 663 (1991), nas pp. 677-678.

${ }^{29}$ Branzburg vs. Hayes, 408 U.S. 665 (1972).

${ }^{30}$ Branzburg vs. Hayes, 408 U.S. 665 (1972), Justice Stewart (vencido, acompanhado dos Justices Brennan e Marshall e apoiado no resultado também por Douglas), nas pp. 725-727.
} 


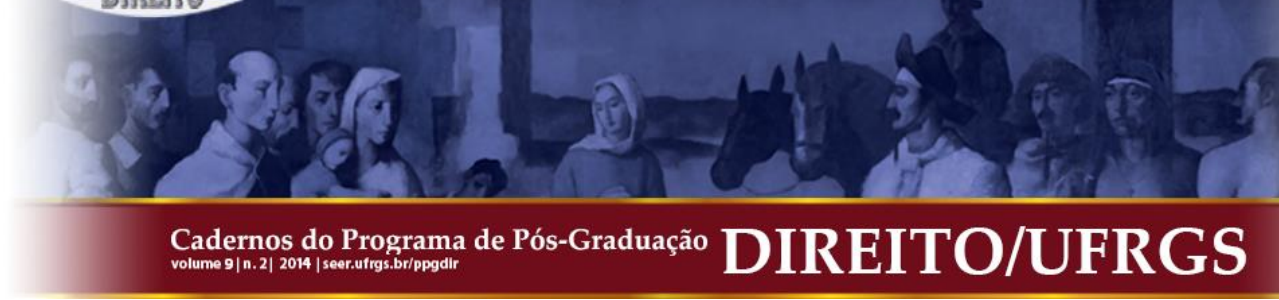

historicamente para garantir - um papel estrutural da imprensa no quadro constitucional, indo muito além da função de um mero veículo de informação. $\mathrm{Na}$ opinião de Stewart, o dispositivo que garante uma imprensa livre foi projetado para garantir à imprensa um papel institucional como um "Quarto Poder" - um corpo organizado de especialistas que realiza um controle adicional sobre o poder público, um suplemento aos freios e contrapesos já em vigor entre os três ramos. ${ }^{31} \mathrm{O}$ ponto de vista minoritário de Stewart representa uma concepção diferente da imprensa como uma "guardiã privilegiada".

\section{A IMPRENSA COMO UM “CÃO DE GUARDA PRIVILEGIADO”}

Em uma concepção mais ampla, a liberdade de imprensa não somente supõe a liberdade de publicação irrestrita. Acima de tudo, a liberdade de imprensa fornece uma garantia institucional da imprensa em seu papel constitucional como "cão de guarda público" - ou seja, organismo de informações e controle em nome do público. O exercício efetivo dessa função implica alguma proteção especial da imprensa, incluindo privilégios, assim como pode implicar regulamentação especial para preservar a independência e pluralismo da imprensa.

\subsection{Liberdade de Imprensa no Direito Constitucional Alemão}

O Tribunal Constitucional alemão tem se apoiado na concepção de "cão de guarda privilegiado" da liberdade de imprensa. O artigo 5 (1) da Constituição alemã prevê uma proteção separada da "liberdade de imprensa". O Tribunal Constitucional alemão, no seu leading case sobre a liberdade de imprensa, o "caso Spiegel", de 1966, interpretou que o dispositivo que garante a imprensa livre no artigo $5 .^{\circ}$ prevê uma proteção institucional de imprensa e garante à imprensa uma determinada posição privilegiada:

Uma imprensa livre, independente do Estado e livre de censura, é um elemento
fundamental em um Estado livre; especialmente, a imprensa política livre e
periódica é indispensável para a democracia moderna. [...] A imprensa funciona
como o informante do debate público. Por meio da imprensa, a opinião pública é
articulada [...]. Em uma democracia representativa a imprensa funciona, além disso,
como um organismo de conexão e controle constante entre o povo e os seus
representantes eleitos no Parlamento e Governo [...]. Essa função da imprensa livre
em um estado democrático corresponde à sua posição jurídica nos termos da
Constituição [Art. 5]. Mesmo que essa disposição, de acordo com o seu contexto e
seu significado tradicional, garanta, em primeiro lugar, um direito subjetivo às

${ }^{31}$ STEWART, Potter. Or of the Press. Hastings Law Journal, v. 26, pp. 631-643, 1975. Para um ponto de vista similar ver BEZANSON, Randall P. The Developing Law of Editorial Judgment. Nebraska Law Review, v. 78, pp. 754-857, 1999. 


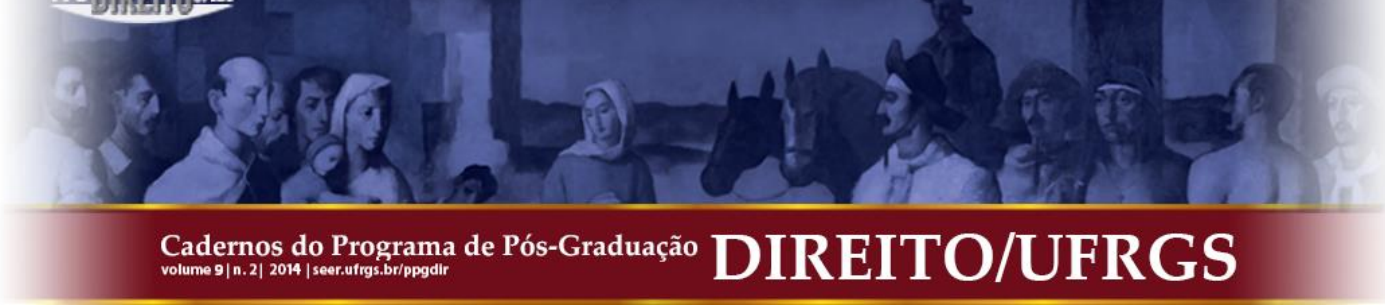

pessoas e empresas que trabalham na imprensa, protegendo-as de restrição do Estado e garantindo-lhes em certos contextos uma posição privilegiada, a disposição tem também um aspecto objetivo. Ela garante a instituição "imprensa livre". O Estado - independente de direitos subjetivos dos indivíduos - possui uma obrigação de levar em consideração a liberdade de imprensa em todo o seu sistema jurídico, quando o âmbito de uma norma jurídica afeta a imprensa. ${ }^{32}$

Na decisão, o Tribunal Constitucional também deixou claro que a liberdade de imprensa protege a imprensa nas suas atividades de procurar informação e que, portanto, ela deve proporcionar alguma proteção especial da confidencialidade entre a imprensa e seus informantes:

\begin{abstract}
A autonomia da imprensa garantida pelo Art. 5 cobre tudo desde a coleta de informações à divulgação de notícias e opiniões. Por isso, certa proteção da confidencialidade entre a imprensa e seus informantes privados também é uma parte da liberdade de imprensa. Essa proteção é indispensável, uma vez que a imprensa não pode funcionar adequadamente sem informações privadas, mas essa fonte de informação só continuará fluindo, quando o informante puder confiar basicamente que o "sigilo editorial" será respeitado. ${ }^{33}$
\end{abstract}

No que diz respeito a privilégios especiais da imprensa em geral, o Tribunal

Constitucional sublinhou que tais privilégios são concedidos estritamente no interesse do público a ser informado, e sua justificação deve ser sempre avaliada, ponderando os interesses colidentes em causa em circunstâncias especiais:

A posição privilegiada da imprensa em certos aspectos é admitida por causa de sua tarefa e apenas dentro dos limites dessa tarefa. Isso não tem nada a ver com privilégios pessoais; isenções de normas jurídicas de aplicação geral sempre devem ser justificáveis em função das circunstâncias específicas de cada caso, conforme medido em relação ao tipo e alcance da isenção. ${ }^{34}$

O Tribunal Constitucional, em conformidade, qualificou a cláusula de restrição prevista no artigo 5 (2) da Constituição alemã, que prevê que a liberdade de expressão e de imprensa deve "encontrar os seus limites nas disposições das leis gerais $[. .]$.$" ". O Tribunal interpreta essa$ disposição no sentido de que a liberdade de imprensa só pode ser restringida, até mesmo por

\footnotetext{
32 “Caso Spiegel” (1966), BUNDESVERFASSUNGSGERICHT (Hrsg.). Spiegel-Urteil. In: Entscheidungen des Bundesverfassungsgerichts. Bd. 20. Tübingen: Mohr, 1967, nas pp. 174-175 (minha tradução do alemão).

33 “Caso Spiegel” (1966), BUNDESVERFASSUNGSGERICHT (Hrsg.). Spiegel-Urteil. In: Entscheidungen des Bundesverfassungsgerichts. Bd. 20. Tübingen: Mohr, 1967, na p. 176 (minha tradução do alemão).

34 “Caso Spiegel” (1966), BUNDESVERFASSUNGSGERICHT (Hrsg.). Spiegel-Urteil. In: Entscheidungen des Bundesverfassungsgerichts. Bd. 20. Tübingen: Mohr, 1967, na p. 176 (minha tradução do alemão).
} 


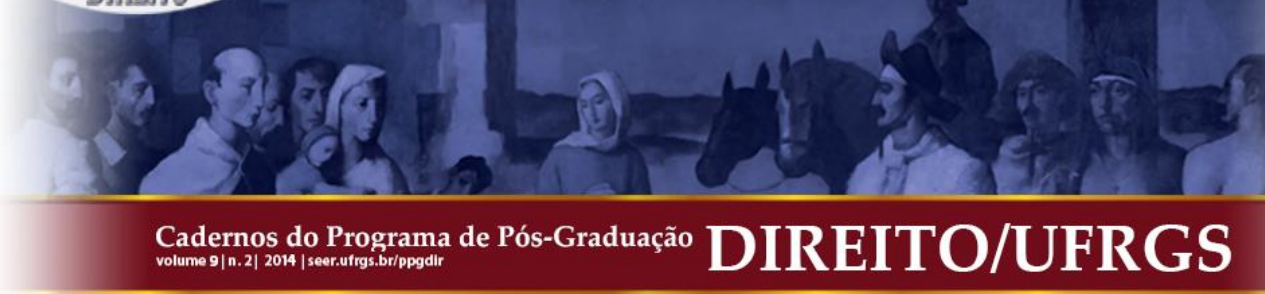

leis gerais, quando interesses com pelo menos o mesmo valor constitucional da liberdade de imprensa tornem essa restrição estritamente necessária. ${ }^{35}$

A abordagem do Tribunal Constitucional alemão, assim, mantém claramente em aberto a possibilidade de privilégios de imprensa especiais, incluindo o privilégio de estar, em determinadas circunstâncias, isenta de a legislação geral restringir o acesso da imprensa a informações importantes.

\subsection{Liberdade de Imprensa no Âmbito da Convenção Europeia dos Direitos Humanos}

O Tribunal Europeu dos Direitos Humanos, em Estrasburgo, inspirado ou não pelo Tribunal Constitucional alemão, também optou por uma concepção de "cão de guarda privilegiado" da liberdade de imprensa. A Convenção Europeia dos Direitos Humanos $(\mathrm{CEDH})$ não contém qualquer disposição específica a respeito da imprensa livre; no entanto, o artigo 10 sobre liberdade de expressão inclui a liberdade de todos "para receber [...] informações e ideias sem interferência de autoridade pública”. Nessa base, o Tribunal de Estrasburgo estabeleceu uma proteção especial da imprensa e de outros meios de comunicação de massa em seu papel de "cão de guarda público", sendo essa função considerada como um corolário do direito do público de ser informado sobre assuntos de interesse público.

O Tribunal estabeleceu essa abordagem no leading case Sunday Times de 1979, quando o Tribunal reconheceu pela primeira vez uma proteção especial da imprensa e de outros meios de comunicação, afirmando que "que lhes incumbia transmitir informações e ideias" sobre assuntos de interesse público, esse dever correspondendo ao "direito do público de ser devidamente informado". ${ }^{36}$ Essa visão estabeleceu a base da jurisprudência do Tribunal sobre a liberdade de imprensa desde então. Tornando-se ainda mais claro que a função da imprensa não é apenas a de fornecer informação independente, mas também a de autoridade de controle em nome do público, o Tribunal apresentou posteriormente a concepção da imprensa e de outros meios de comunicação de massa como uma instituição que executa a tarefa de "cão de

\footnotetext{
35 “Caso Spiegel” (1966), BUNDESVERFASSUNGSGERICHT (Hrsg.). Spiegel-Urteil. In: Entscheidungen des Bundesverfassungsgerichts. Bd. 20. Tübingen: Mohr, 1967, na p. 177.

${ }^{36}$ Sunday Times c. Reino Unido, julgamento plenário de 29 abr. 1979, Ap. nº. 6538/74, parágrafos 65-66. O caso dizia respeito a uma restrição via contempt of court sobre a publicação de artigos de jornal relativos a um litígio em curso.
} 


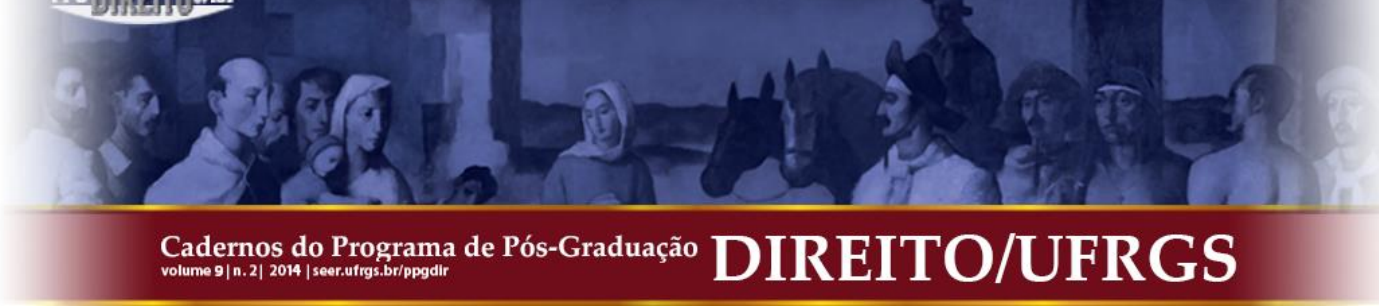

guarda público". ${ }^{37} \mathrm{O}$ ponto de vista geral do Tribunal de Estrasburgo sobre a importância e o papel da imprensa foi resumido em Jersild:

\begin{abstract}
A liberdade de expressão constitui um dos fundamentos essenciais de uma sociedade democrática e as garantias de que a imprensa goza revestem uma importância particular. Embora a imprensa não deva ultrapassar certos limites, entre outras coisas, no respeito por [...] incumbe-lhe, no entanto, comunicar informações e ideias de interesse geral. Não apenas a imprensa tem a função de divulgar tais informações e ideias; o público tem o direito de recebê-las. Não fosse assim, a imprensa não desempenharia o seu papel indispensável de cão de guarda público. ${ }^{38}$
\end{abstract}

O Tribunal de Estrasburgo reconhece assim claramente que o papel da imprensa como “cão de guarda público" é uma função estrutural, que é crucial para a democracia, referindose em Bladet Troms $\phi$ a "a função essencial que a imprensa cumpre em uma sociedade democrática". ${ }^{39}$ A essência dessa função democrática de "cão de guarda" é o controle persistente do poder público: "Em um sistema democrático as ações ou omissões do Governo devem estar sujeitas a um exame minucioso, não só pelas autoridades legislativas e judiciais, mas também pela imprensa e opinião pública." 40

No entanto, até que ponto o seu papel de "cão de guarda público" faz merecer privilégios especiais à imprensa em suas atividades de reunir informações? No caso Goodwin o Tribunal de Estrasburgo, em contraste com a Suprema Corte dos Estados Unidos, mas alinhado com o Tribunal Constitucional alemão, declarou que preservar o papel de "cão de guarda público" da imprensa implica necessariamente uma ampla proteção da confidencialidade das fontes jornalísticas, uma vez que rejeitar tal proteção impediria o acesso da imprensa a informações importantes e, consequentemente, poderia minar o seu papel de "cão de guarda público":

A proteção das fontes jornalísticas é uma das condições básicas para a liberdade de imprensa conforme se reflete nas leis e nos códigos de conduta profissional em vários Estados contratantes e se afirma em diversos instrumentos internacionais sobre liberdades jornalísticas. [...] Sem essa proteção, fontes podem ser impedidas

\footnotetext{
${ }^{37}$ O Tribunal usou pela primeira vez o termo "cão de guarda" no caso Barthold c. Alemanha, julgamento de 25 mar. 1985, Ap. $\mathrm{n}^{\circ} .8734 / 79$, parágrafo 58, afirmando que a imprensa tem uma "tarefa de fornecedora de informação e de cão de guarda público".

${ }^{38}$ Jersild c. Dinamarca, julgamento da Grande Câmara de 23 set. 1994, Ap. nº. 15890/89, parágrafo 31. O caso em questão tratou da condenação de um jornalista pela divulgação de um discurso de ódio por meio de uma entrevista transmitida em um programa de televisão.

${ }^{39}$ Bladet Tromsø c. Noruega, julgamento da Grande Câmara de 20 maio 1999, Ap. nº. 21980/93, parágrafo 59.

${ }^{40}$ Castells c. Espanha, julgamento de 23 abr. 1992, Ap. ${ }^{\circ}$. 11798/85, parágrafo 46; Özgür Radyo-Ses Radyo Televizyon Yayin Yapim Ve Tanitim A.Ş. c. Turquia ( ${ }^{\circ}$. 1), julgamento de 30 mar. 2006, Ap. $n^{\circ}$. 64178/00 et al, parágrafo 78 .
} 


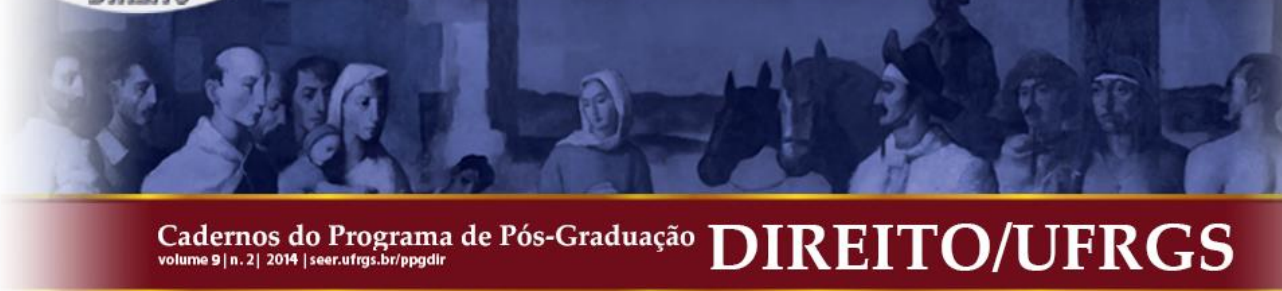

de ajudar a imprensa para informar o público a respeito de questões de interesse público. Como resultado, o vital papel de cão de guarda público da imprensa pode ser minado e a capacidade da imprensa de fornecer informações precisas e confiáveis pode ser negativamente afetada. Tendo em conta a importância da proteção das fontes jornalísticas para a liberdade de imprensa em uma sociedade democrática e o potencial efeito inibidor que uma ordem de divulgação da fonte tem no exercício dessa liberdade, tal medida não pode ser compatível com o artigo $10^{\circ}$ da Convenção, a menos que seja justificada por uma razão imperiosa de interesse público. $^{41}$

Apenas um dos 18 juízes que participaram do julgamento do caso Goodwin rejeitou o parecer do Tribunal. O Juiz Walsh - ao ecoar a posição da Suprema Corte dos Estados Unidos - no seu voto vencido afirmou com descrença:

[P]arece-me que o Tribunal, em sua decisão, decidiu no sentido de que ao abrigo da
Convenção um jornalista, em virtude de sua profissão, deve dispor de um privilégio
não disponível para outras pessoas. Não deve o cidadão comum, ao escrever uma
carta aos jornais para publicação, dispor de privilégios iguais, mesmo que ele não
seja um jornalista profissional? Distinguir entre o jornalista e o cidadão comum deve
pôr em causa a disposição do artigo 14 [que proíbe a discriminação]. ${ }^{42}$

O Tribunal de Estrasburgo confirmou, assim, que a imprensa, no seu papel de "cão de guarda" dispõe de uma posição privilegiada não só quando ela comunica informações sobre assuntos de interesse público, mas também em seus esforços para obter tais informações. Por conseguinte, pode se presumir que qualquer medida ou legislação que restrinja o acesso da imprensa à coleta de informações pode levantar uma questão nos termos do artigo 10.

Até agora, o Tribunal de Estrasburgo não foi ainda confrontado com um caso claro de um jornalista que agiu em violação de lei de aplicação geral com a finalidade de reunir informações importantes.

No entanto, no caso Fressoz \& Roire - relativo a um jornalista condenado por ter usado documentos confidenciais obtidos a partir de uma fonte desconhecida, em violação dos seus deveres pessoais de confidencialidade, estando tal uso proibido pela legislação nacional - o Tribunal de Justiça declarou que os jornalistas não estão totalmente isentos de observar o direito penal comum, mesmo que eles atuem como "cães de guarda públicos". No entanto, ao mesmo tempo, o Tribunal parece pressupor que a necessidade de proteger a possibilidade de

\footnotetext{
${ }^{41}$ Goodwin c. Reino Unido, julgamento da Grande Câmara de 27 mar. 1996, Ap. nº 17488/90, parágrafo 39.

${ }^{42}$ Goodwin c. Reino Unido, julgamento da Grande Câmara de 27 mar. 1996, Ap. nº 17488/90, voto vencido em separado do juiz Walsh, parágrafo 1 .
} 


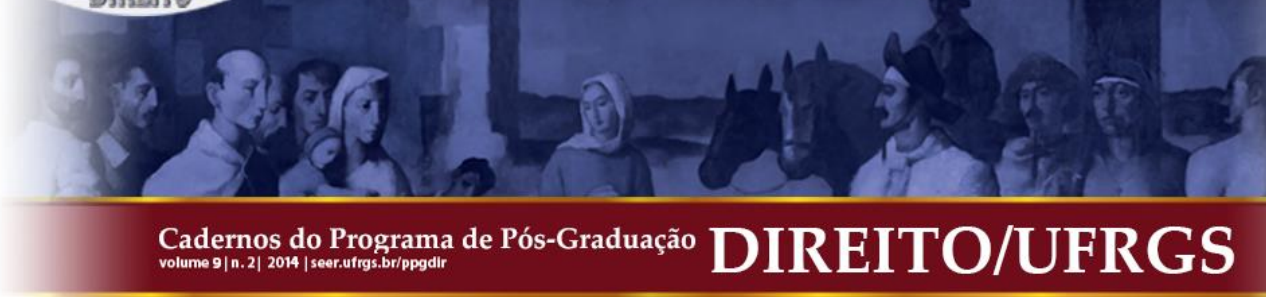

os jornalistas informarem o público possa de vez em quando preponderar sobre a necessidade de aplicar a lei penal geral: ${ }^{43}$

\begin{abstract}
Embora reconhecendo o papel fundamental desempenhado pela imprensa em uma sociedade democrática, o Tribunal salienta que os jornalistas não podem, em princípio, ser dispensados do dever de obedecer à lei penal comum sob a alegação de que o artigo 10 confere-lhes proteção. Com efeito, o parágrafo 2 do artigo 10 define os limites do exercício da liberdade de expressão. Cabe ser decidido se, nas circunstâncias específicas do caso concreto, o interesse do público em ser informado prepondera sobre os "deveres e responsabilidades" que os requerentes tinham como resultado da origem suspeita dos documentos que lhes foram enviados. ${ }^{44}$
\end{abstract}

A implicação é que nos termos do artigo 10 uma isenção jornalística da lei penal comum não é a regra, mas a exceção. No entanto, isso deixaria espaço para ponderar os interesses conflitantes em casos específicos, considerando-se em conformidade com o artigo 10 (2) se a restrição da coleta de informação jornalística é “necessária em uma sociedade democrática", ou seja, proporcional ao objetivo perseguido.

No caso Dammann - relativo a um jornalista condenado por instigar uma quebra de sigilo ao pedir e obter informações confidenciais de um assistente administrativo do escritório do Promotor de Justiça - o Tribunal confirmou que as atividades do jornalismo investigativo realizado para coletar informações de interesse público são protegidas pelo artigo 10, como parte da liberdade de imprensa, e que o Tribunal leva a sério restrições sobre tais atividades, mesmo que decorram da aplicação da lei geral. Relevantemente, o Tribunal de Justiça declarou, em termos gerais, o seguinte:

O Tribunal salienta que esse caso não diz respeito a uma restrição de publicação, como tal, ou a uma condenação pós-publicação, mas a um ato preparatório à publicação, i.e., atividades de pesquisa e investigação levadas a cabo por um jornalista. [...] Não apenas as restrições à liberdade de imprensa a respeito da fase de pré-publicação são abrangidas pelo âmbito da revisão do Tribunal de Justiça, mas elas também representam grande perigo e, portanto, exigem o escrutínio mais minucioso por parte do Tribunal $\left[\ldots . . .{ }^{45}\right.$

O Tribunal de Estrasburgo, como o Tribunal Constitucional alemão, assim, parece aberto a aceitar, em certas circunstâncias, que os jornalistas devem ser isentos do direito penal comum quando tiverem agido com a finalidade de obter informações de interesse público.

\footnotetext{
43 Ver também KJØLBRO, Jon Fridrik. Den Europaiske Menneskerettighedskonvention forpraktikere. 2. udgave. København: Jurist- og Økonomforbundets Forlag, 2007, p. 656.

${ }^{44}$ Fressoz \& Roire c. França, julgamento da Grande Câmara de 21 jan. 1999, Ap. no. 29183/95, parágrafo 52.

${ }^{45}$ Dammann c. Suíça, julgamento de 25 abr. 2006, Ap. no . 77551/01, parágrafo 52 (minha tradução do francês).
} 


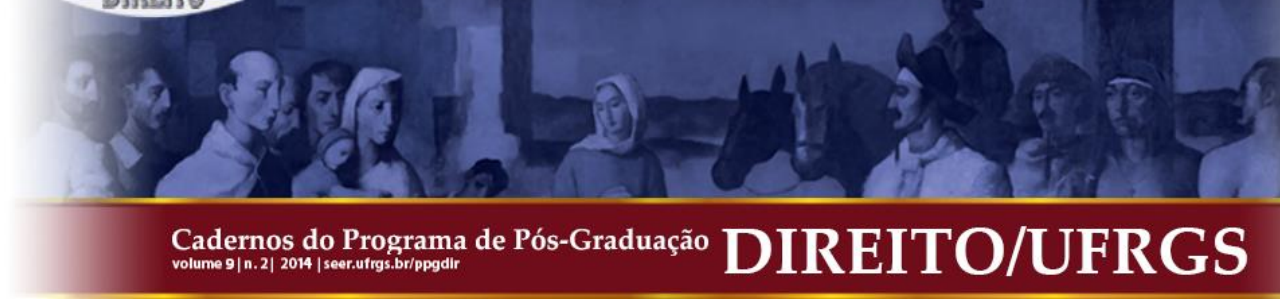

Está longe de estar claro, no entanto, até que ponto esse privilégio pode se estender, pois não há casos de Estrasburgo até agora a respeito de atividades ilegais de jornalismo investigativo a fim de obter informações que ninguém estava disposto a fornecer.

\subsection{Vantagens da Doutrina do "cão de guarda privilegiado"}

A atração clara da doutrina do "cão de guarda privilegiado" é que ela garante que a imprensa será eficaz em sua função de "cão de guarda público", uma vez que só pode ser restringida em seus esforços de recolher e divulgar informações de interesse público, mesmo pelas leis gerais, quando, nas circunstâncias de cada caso, razões imperiosas assim o exigirem.

\subsection{Objeções à Doutrina do "cão de guarda privilegiado"}

A concepção de liberdade de imprensa como "guardiã privilegiada", fornecendo proteção e certos privilégios à "imprensa", será incomodada em pelo menos dois aspectos: como definir a "imprensa (e outros meios de comunicação)" privilegiada e como determinar a extensão dos privilégios de imprensa vis-à-vis o princípio colidente da igualdade de todos perante a lei - seja civil ou criminal. ${ }^{46}$ As duas seções seguintes serão dedicadas a esses problemas de definição e delimitação.

\section{QUAL É “A IMPRENSA" QUALIFICADA PARA PRIVILÉGIOS DE CÃO DE GUARDA?}

Enquanto que definir a imprensa não apresenta nenhum problema sob a concepção restrita de "fórum aberto" da liberdade de imprensa, a doutrina de um "cão de guarda privilegiado" pressupõe uma determinação de quem pertence e quem não pertence à categoria privilegiada de "a imprensa". Mais especificamente, a questão principal é saber a quem deve ser concedido um privilégio especial de estar isento da lei geral no processo de recolhimento de informações a respeito de questões de interesse público. Essencialmente, as opções são uma definição funcional ou institucional de "a imprensa".

\footnotetext{
${ }^{46}$ Cf. a opinião majoritária em Branzburg vs. Hayes, 408 U.S. 665 (1972), nas pp. 702-704.; LANGE, David. The Speech and Press Clauses. U.C.L.A. Law Review, v. 23, pp. 77-119, 1975.
} 


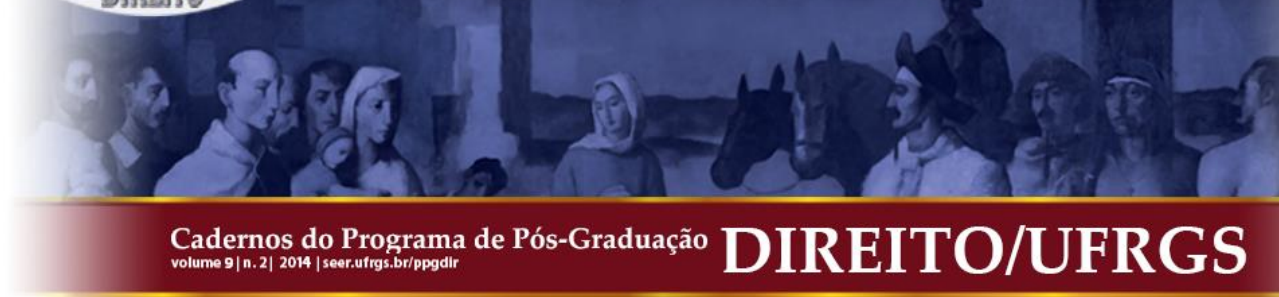

Uma definição funcional de "imprensa" sustentaria que mesmo as atividades de coleta de informações realizadas por particulares podem se qualificar ao privilégio de jornalista, com a condição de que a atividade foi, desde o início, realizada para fins de publicação posterior ao público. Um tribunal de apelação federal dos EUA tomou exatamente essa posição em um processo relativo à proteção de material confidencial contra uma ordem judicial para produzilo, afirmando que:

[U]m indivíduo pode com êxito reivindicar privilégio de jornalista se ele está envolvido em atividades tradicionalmente associadas a coleta e difusão de notícias [a coleta de informação para fins de divulgação ao público], mesmo que ele não seja normalmente um membro da imprensa institucionalizada. ${ }^{47}$

Paul Horwitz sugeriu uma definição um pouco semelhante (levando a tecnologia da informação moderna em conta), mas exige que a atividade jornalística privada deva ser realizada regularmente: “[U]m indivíduo que está envolvido em um processo que se destina a gerar e divulgar informações verdadeiras para o público regularmente". ${ }^{48}$ Deixando de lado os problemas óbvios de provas, tal definição da "imprensa" pode parecer muito ampla para o conceito de "cão de guarda.

Uma definição institucional da "imprensa" parece mais de acordo com a lógica e a tradição da concepção de "cão de guarda privilegiado". Assim, o Justice Stewart considera que a imprensa privilegiada inclui "a imprensa organizada [...] os jornais diários e outros meios de comunicação estabelecidos". ${ }^{49}$ Claramente, o Tribunal Constitucional alemão tinha em mente uma imprensa institucional/profissional quando se afirmou no caso Spiegel que "a imprensa funciona [...] como um organismo de conexão e controle constante [...]", falou de um direito subjetivo pertencente a "pessoas e empresas que trabalham na imprensa" e, ao reconhecer a proteção da confidencialidade, considerou que "a imprensa não pode funcionar adequadamente sem informação privada". ${ }^{50} \mathrm{Da}$ mesma forma, quando o Tribunal de Estrasburgo no caso Goodwin reconheceu uma ampla proteção das fontes jornalísticas como condição básica da liberdade de imprensa, estava se referindo aos jornalistas pertencentes à

\footnotetext{
${ }^{47}$ Von Bülow by Auersperg vs. von Btilow, 11 F 2d 136 (2d. Cir. 1987).

${ }^{48}$ HORWITZ, Paul. Or of the [blog]. Excerpt reprinted. In: EPPS, Garrett (Ed.). The First Amendment. Freedom of the press: its constitutional history and the contemporary debate. Amherst: Prometheus Books, 2008, p. 329.

${ }^{49}$ STEWART, Potter. Or of the Press. Hastings Law Journal, v. 26, pp. 631-643, 1975.

${ }^{50}$ Ver acima seção 3 .
} 


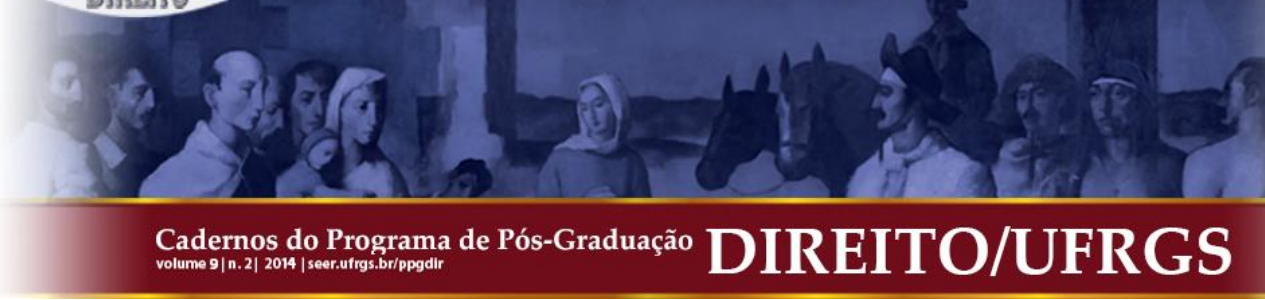

imprensa organizada, amparando sua argumentação na referência aos "códigos de conduta profissional" em muitos Estados contratantes, e à recomendação sobre liberdades jornalísticas do Conselho da Europa de 1994. ${ }^{51}$ A última recomendação declara em seu preâmbulo que "as funções de todos os envolvidos na prática do jornalismo, em particular os jornalistas, editores, editores, diretores e proprietários, nos diferentes meios de comunicação eletrônicos e impressos são essenciais”, e refere-se várias vezes aos códigos de conduta profissional. ${ }^{52}$

Às vezes, em um contexto diferente, o Tribunal de Estrasburgo tem interpretado o termo "imprensa" de forma mais ampla. Assim, o Tribunal de Justiça atribuiu a jornalistas um privilégio de ampla liberdade de expressão em assuntos de interesse público, sustentando que “a liberdade jornalística também abrange o eventual recurso a um grau de exagero ou mesmo de provocação". ${ }^{53}$ Parece difícil de justificar o porquê tal privilégio deveria ser estendido apenas a jornalistas. Não profissionais podem contribuir tanto para o debate público quanto jornalistas e precisam de uma margem de exagero e provocação, pelo menos tanto quanto o jornalista profissional. ${ }^{54}$ Assim, não é surpreendente que o Tribunal de Estrasburgo teve de estender esse privilégio para outros que não fossem da imprensa profissional. Assim, nos casos em matéria de difamação, o Tribunal decidiu que a liberdade jornalística de exagero e provocação se estende também à publicação de "livros ou outros materiais escritos, como periódicos [...], se dizem respeito a questões de interesse da geral" ${ }^{, 55}$ e até mesmo a uma agência local de uma ONG (Greenpeace) engajada em uma campanha anti-McDonald's, considerando que "em uma sociedade democrática mesmo grupos de campanha pequenos e informais, como o Greenpeace de Londres, devem ser capazes de exercer as suas atividades de forma eficaz e que existe um forte interesse público na habilitação de tais grupos e indivíduos de fora do mainstream para que contribuam para o debate público por meio da divulgação de informações e ideias a respeito de questões de interesse público". ${ }^{56}$ Essa é, essencialmente, uma questão de liberdade de expressão geral na forma de publicação e, assim,

\footnotetext{
${ }^{51}$ Ver acima seção 3.

${ }^{52}$ Recomendação sobre Liberdades e Direitos Humanos Jornalísticos, aprovada na $4^{\text {a }}$ Conferência Ministerial Europeia sobre Políticas de Mídia de Massa, realizada em Praga de 7 a 8 de dezembro de 1994. Disponível em < www.coe.int/T/E/ConFiles/Events/2002-09-Media/ ConfMedial994.asp >. Acesso em 2010.

${ }^{53}$ Prager \& Oberschlick c. Áustria, julgamento de 26 abr. 1995, Ap. no. 15974/90, parágrafo 38; Pedersen \& Baadsgaard c. Dinamarca, julgamento da Grande Câmara de 17 dez. 2004, Ap. nº. 49017/99, parágrafo 71.

54 Cf. RYTTER, Jens Elo. Den Europaiske Menneskerettighedskonvention - og dansk ret. 2. udgave. København: Thomson, 2006, p. 284.

${ }^{55}$ Chauvy e outros c. França, julgamento de 29 jun. de 2004, Ap. nº 64915/01, parágrafo 68.

${ }^{56}$ Morris \& Steel c. Reino Unido, julgamento de 15 fev. 2005, Ap. nº. 68416/01, parágrafos 88-89.
} 


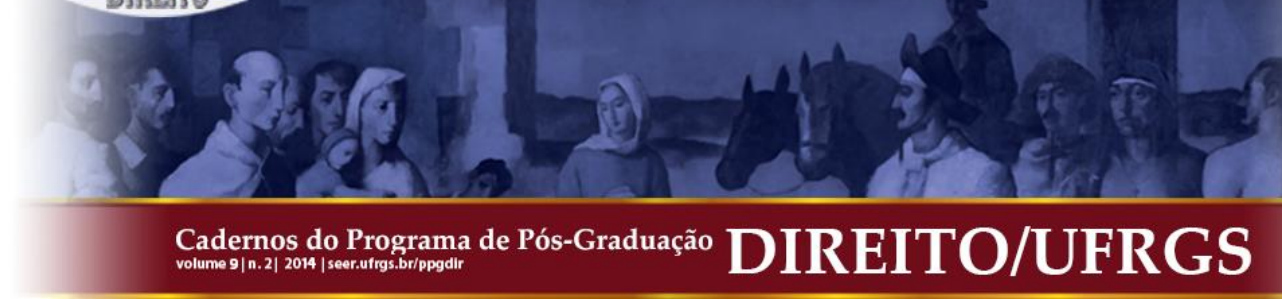

estendê-la a todos que publiquem a respeito de assuntos de interesse público corresponde à concepção "fórum aberto" da liberdade de imprensa. Em outras palavras, o Tribunal de Estrasburgo, em minha opinião, concebeu mal ao descrever inicialmente a liberdade de exagerar e provocar como uma liberdade de imprensa especial e, portanto, sem surpresa, foi forçado a estendê-la a outros oradores que tratem de assuntos de interesse público. Essa jurisprudência, portanto, não tem qualquer influência imediata sobre a definição de imprensa em relação aos privilégios especiais de "cão de guarda" que digam respeito ao acesso para obter informações.

A mesma concepção institucional - mas sem exclusividade em termos de establishment - está na base da lei dinamarquesa a respeito da responsabilidade dos meios de comunicação (e leis semelhantes em muitos outros países). A lei contém uma responsabilidade especial da mídia que prevê, dentre outras coisas, para a responsabilidade editorial, o dever de retratação e permitir direito de resposta etc. De acordo com o $\S 1$ da Lei, ela se aplica a (1) jornais e outras publicações periódicas, (2) televisão e empresas de rádio e (3) outras fontes periódicas de notícias/informações de natureza semelhante, se os responsáveis optam por registrar-se para ser incluídos. Ela inclui, portanto, a imprensa estabelecida (established) e meios de comunicação de massa, mas também está aberta a outros agentes de notícias periódicas. A beleza desse sistema é que ele estabelece uma correlação entre estar sujeito a responsabilidades especiais e códigos de conduta profissional e desfrutar de privilégios especiais, uma vez que de acordo com o $\S 172$ da lei dinamarquesa a respeito do processo judicial, apenas as pessoas relacionadas com a mídia descritas no $\S 1$ da lei a respeito da responsabilidade dos meios de comunicação têm o direito de ter suas fontes jornalísticas protegidas por estar isentas de testemunhar a respeito de sua identidade.

Tal concepção institucional de "a imprensa", que se baseia em uma correlação de direitos especiais e privilégios especiais parece se encaixar na lógica do artigo 10 (2) da CEDH, referindo-se aos "direitos e responsabilidades" inerentes à liberdade de expressão e de informação.

Em suma, uma definição institucional/profissional de "a imprensa", onde privilégios especiais no processo de coleta de informações corresponderiam às responsabilidades especiais e códigos de conduta profissional, seria preferível, se não necessária, de acordo com a concepção de "cão de guarda privilegiado" da liberdade de imprensa. 


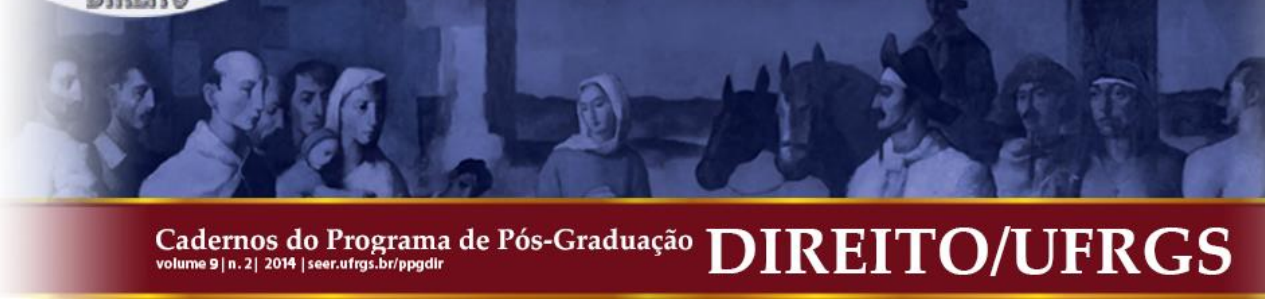

\section{EM QUE MEDIDA O PRIVILÉGIO DE IMPRENSA CÃO DE GUARDA DEVERIA SE ESTENDER?}

Deve ser relembrado que o dilema de privilégios de imprensa não diz respeito a restrições específicas ao acesso da imprensa e de outros meios de comunicação de massa à informação, uma vez que tais restrições específicas seriam claramente prima facie contrárias à liberdade de imprensa. A delicada questão refere-se à amplitude em que a imprensa "cão de guarda" deve estar isenta da legislação geral que incidentalmente restringe o seu acesso para obter informações de interesse público.

Na concepção tradicional de "fórum aberto" da liberdade de imprensa, não há espaço para privilégios especiais; as leis gerais são aplicáveis à imprensa assim como para qualquer outra pessoa. Assim, não há nenhum potencial conflito entre o princípio da igualdade perante a lei e da liberdade de imprensa, uma vez que esta última simplesmente opera dentro dos limites da legislação ordinária. Pelo contrário, na concepção de imprensa como um "cão de guarda" institucional, privilégios especiais são reconhecidos como, às vezes, justificáveis quando considerados necessários para o cumprimento efetivo pela imprensa de sua função constitucional de cão de guarda.

Como vimos, a coleta de informações de interesse público é uma atividade protegida, em princípio, pela liberdade da imprensa "cão de guarda". ${ }^{57} \mathrm{Na}$ medida em que leis gerais podem incidentalmente restringir o acesso da imprensa a obter essas informações, há um potencial conflito entre a liberdade de imprensa e a aplicação da igualdade perante a lei, que deve ser resolvido por meio de uma ponderação dos interesses colidentes envolvidos em cada caso, como tem foi reconhecido pelo Tribunal Constitucional alemão e, aparentemente, também pelo Tribunal de Estrasburgo. A necessidade dessa abordagem ponderativa, mesmo no que diz respeito às limitações da coleta de informação causada por leis gerais, está em conformidade com o ponto de vista minoritário do Justice Souter da Suprema Corte, que

\footnotetext{
${ }^{57}$ Veja também Recomendação sobre Liberdades e Direitos Humanos Jornalísticos, aprovada na $4^{\mathrm{a}}$ Conferência Ministerial Europeia sobre Políticas de Mídia de Massa, realizada em Praga de 7 a 8 de dezembro de 1994, Princípio 7: “A prática do jornalismo em uma verdadeira democracia tem uma série de implicações. Essas implicações, que já estão refletidas em muitos códigos de conduta profissional, incluem: a) respeitar o direito do público de ser informado fielmente a respeito de fatos e eventos; b) a coleta de informações por meios justos [...]". A resolução está disponível em < www.coe.int/T/E/ConFiles/Events/2002-09-Media/ ConfMedial994.asp >. Acesso em 2010.
} 


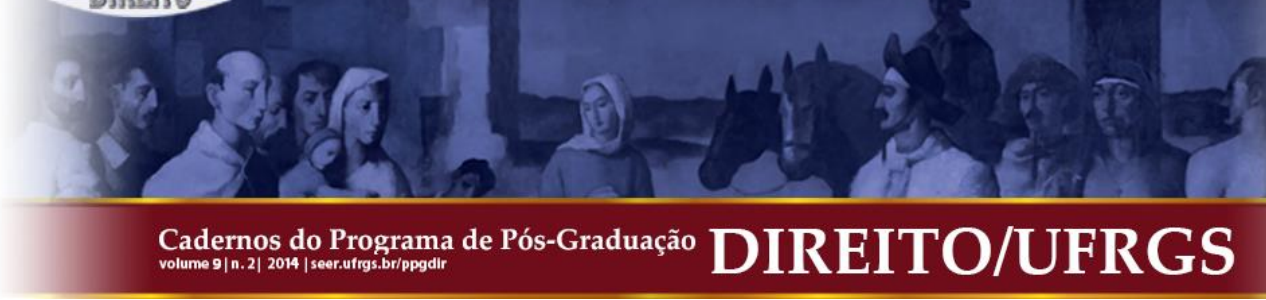

também sublinha muito sensatamente que é relevante ponderar como a informação foi adquirida pela imprensa:

Porque eu não acredito no fato de a aplicabilidade geral ser dispositiva, acho que é necessário articular, medir e comparar os interesses competidores presentes em qualquer caso, para determinar a legitimidade de impor um ônus a interesses constitucionais [...]. Nem eu quero dizer que as circunstâncias de aquisição [de informações] são irrelevantes para a ponderação [...] embora possam apenas apontar em direção ao que pesa contra, mas não diminuir o valor de Primeira Emenda [liberdade de imprensa] que contém qualquer pedaço específico de informação. ${ }^{58}$

Evidentemente, o privilégio/imunidade de imprensa a ser isento da legislação ordinária não pode ser absoluto. Assim, enquanto que uma proteção testemunhal de longo alcance das fontes jornalísticas tem sido considerada como inerente ao papel da imprensa como cão de guarda público, em outras situações pode ser igualmente óbvio que não pode haver imunidade mesmo para a imprensa. Enquanto que ponderar é rotina nas sentenças de direitos humanos, delimitar a extensão dos privilégios de imprensa pode representar um exercício especialmente complexo, notavelmente quando as leis que, incidentalmente, restringem o acesso da imprensa à coleta de informação possam não estar limitando a informação, mas apenas a ação. No entanto, um ponto de partida útil para a delimitação de privilégios de imprensa pode ser fazer uma distinção entre proteger por privilégio/imunidade especial a capacidade da imprensa para (1) receber informações de outras pessoas que estão dispostas a fornecê-las e (2) adquirir as tais informações mesmo quando ninguém está disposto a fornecê-las.

\subsection{Um Privilégio para Receber Informação}

Subjacente ao clássico privilégio testemunhal [sigilo de fonte] para proteger as fontes jornalísticas, que foi sancionado pelo Tribunal Constitucional alemão, bem como pelo Tribunal de Estrasburgo como inerente à concepção "cão de guarda" da liberdade de imprensa, é que ele é necessário, caso as fontes estejam dispostas a fornecer informações relevantes para a imprensa e, consequentemente, para o público. Tal privilégio representa uma isenção especial da imprensa de um dever jurídico geral. O privilégio concedido está interessado em manter aberto à imprensa um importante canal de informações. A imprensa

58 Justice Souter (voto vencido em nome de quarto juízes) em Cohen vs. Cowles Media Co., 501 U.S. 663 (1991), nas pp. 677-679. 


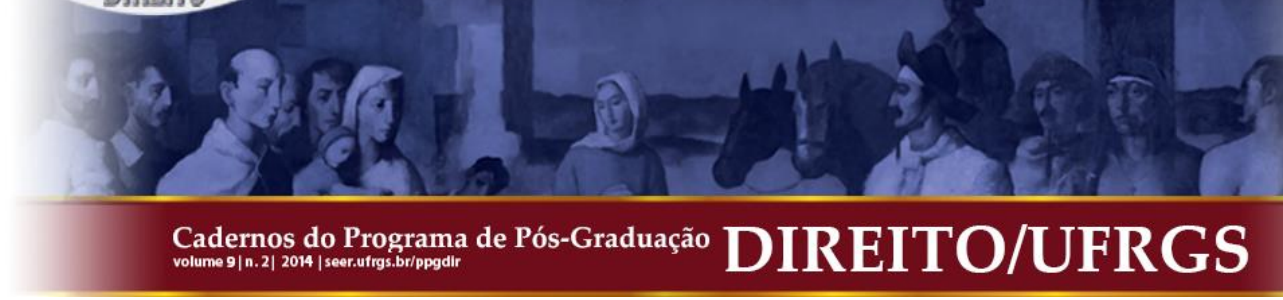

não adquire essa informação por meios ilícitos. Se a proteção das fontes jornalísticas é considerada essencial para a função de "cão de guarda" da imprensa, então, a fortiori, ele restringirá a liberdade de imprensa para penalizar o uso de informações confidenciais assim recebidas, como aconteceu no caso Fressoz \& Roire, ${ }^{59}$ ou penalizar o simples pedido de tal tipo de informação, como aconteceu no caso Dammann. ${ }^{60}$ A característica comum aqui é que a lei geral restringe ou penaliza o acesso da imprensa ao receber informações de alguém que está disposto a fornecê-la. Nesses casos, ao que parece, um privilégio de imprensa a estar isenta de tais leis deve ser a regra, e a aplicação da legislação geral contra a imprensa, a isenção a ser justificada por razões imperiosas, cf. Goodwin (no que diz respeito às fontes jornalísticas). ${ }^{61}$

\subsection{Um Privilégio para Buscar Informações}

É uma coisa diferente permitir a um jornalista agir por iniciativa própria, em violação da lei geral, a fim de obter informações que ninguém está disposto a fornecer. Não pareceria razoável estabelecer um limite rígido aqui, sustentando que a imprensa cão de guarda não goza de privilégio/imunidade se a informação só pode ser obtida por meio do engano ilegal ou do uso da força. Na verdade, o Tribunal de Estrasburgo apontou nessa direção. No caso Dammann um jornalista conseguiu persuadir um assistente administrativo do escritório do Promotor de Justiça a fornecer-lhe informações confidenciais sobre os registos criminais anteriores de determinadas pessoas; por isso, ele foi condenado por ter instigado a violação do sigilo profissional. O Tribunal, considerando que a sua condenação equivalia a uma violação do artigo 10, pareceu enfatizar que tudo o que o jornalista havia feito foi pedir o material: “aparentemente o [jornalista] não recorreu ao engano ou ameaça ou outras formas de pressão para obter as informações." 62

Por outro lado, a busca ativa de informações pelo jornalismo investigativo é reconhecida como sendo a essência do jornalismo cão de guarda - e improvável de ser realizada por qualquer pessoa que não os meios de comunicação de massa organizados, os únicos que possuem os recursos e os conhecimentos necessários. É um fato que a eficácia de

\footnotetext{
${ }^{59}$ Ver acima seção 3.

${ }^{60}$ Ver acima seção 3.

${ }^{61}$ Ver acima seção 3.

${ }^{62}$ Dammann c. Suíça, julgamento de 25 abr. 2006, Ap. nº. 77551/01, parágrafo 55 (minha tradução do francês).
} 


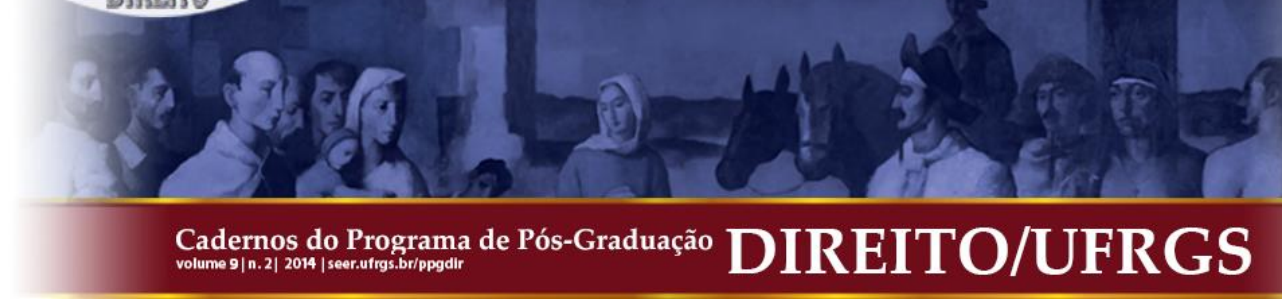

tal jornalismo investigativo requer algumas vezes as violações da lei, especialmente com o propósito de agir "infiltrado". Assim, embora, obviamente, uma isenção da lei possa não ser a regra nesses casos, em minha opinião, não se deve excluir a possibilidade de que, em certos casos, o interesse do público em receber a informação pode preponderar sobre os interesses gerais e específicos de fazer cumprir a lei que foi violada. Se isso for aceito, a próxima pergunta é determinar as circunstâncias em que o interesse da informação pública e, portanto, do funcionamento eficaz da imprensa "cão de guarda" pode preponderar sobre os interesses afetados pela violação.

Em primeiro lugar, uma condição de qualquer isenção da imprensa de leis gerais, sendo de todo relevante, é que a violação do jornalista deve servir para descobrir questões de (significativo) interesse público. Como mencionado anteriormente, a liberdade de imprensa é fundamental para a informação do público; portanto, um privilégio jornalístico especial de estar isento de observar a lei só será justificável à medida que a ação específica promova o direito do público de ser informado sobre assuntos de interesse público.

Em segundo lugar, a ação do jornalista em violação da lei geral deve ser necessária para descobrir a informação relevante. ${ }^{63}$ Não se pode afirmar que o acesso da imprensa (e, portanto, do público) à informação importante sofreu restrição pela legislação geral, se a informação buscada por meio da violação poderia ter sido obtida por outros meios não violem a lei.

Se a violação de um jornalista da lei foi necessária para descobrir questões de (significativo) interesse público, o interesse da informação tem grande peso. A questão é quando o interesse em aplicar a lei, no entanto, ganha uma importância tal que o jornalista deve, contudo, ser punido.

Em terceiro lugar, eu sugiro que deveria ser uma condição da imunidade de imprensa que a violação não tenha envolvido qualquer risco imediato de danos ou prejuízos. No caso Dammann, em que um jornalista foi condenado por instigar uma violação de sigilo profissional, depois de ter persuadido um assistente administrativo no escritório de um Promotor de Justiça para fornecer-lhe antecedentes criminais de pessoas específicas, porém, quando o jornalista acabou por nunca publicar o material, o Tribunal de Estrasburgo aparentemente ressaltou o fato de que nenhum dano específico foi causado a alguém: "Além

${ }^{63}$ Cf. SCHAUMBURG-MULLER, Sten. Presseret. København: Jurist- og Økonomforbundets Forl, 2003, p. 359. 


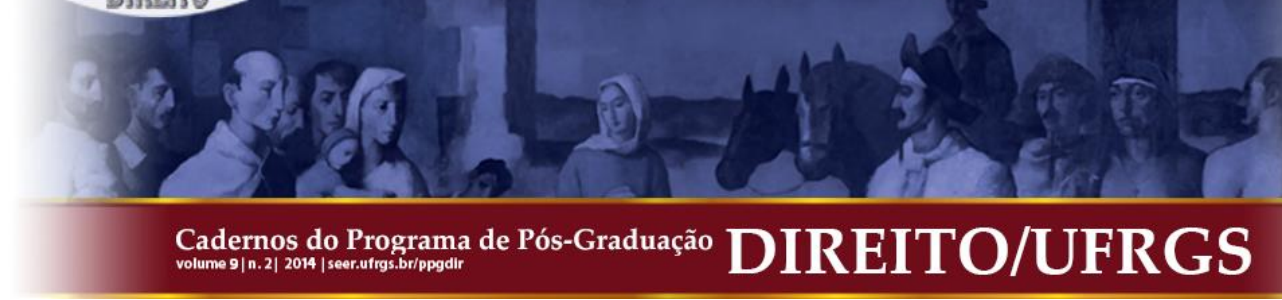

disso, deve notar-se que, neste caso, nenhum dano foi causado aos direitos das pessoas em causa." ${ }^{64}$ Mesmo que a violação tenha sido necessária para descobrir assuntos de interesse público, ela pode, assim, ser razoavelmente punida se a violação envolveu (um risco imediato de) danos ou prejuízos a outras pessoas ou a sociedade como um todo (vida, saúde, privacidade, propriedade, segurança, potências estrangeiras etc.). Por exemplo, um jornalista não pode impunemente roubar um banco para testar o tempo de reação da polícia; pois mesmo que a informação obtida por tal ato fosse de interesse público, isso não poderia preponderar sobre os danos causados às pessoas afetadas por ele (choque, trauma). Ele não pode ter permissão para invadir uma casa de um político para investigar uma questão política, porque isso seria uma violação da casa e da privacidade do político e, portanto, prejudicial para essa esfera muito íntima. Em tais circunstâncias, há uma necessidade social premente de aplicação da lei e, portanto, a condenação do jornalista deve ser pressuposta como justificada por ser “necessária em uma sociedade democrática" nos termos do artigo 10 (2) da CEDH.

Se, no entanto, o único interesse afetado pela violação é o interesse geral da sociedade com a uniformização da aplicação da lei, isso não poderia, por si só, exceder o peso do interesse de informação e, portanto, da liberdade da imprensa cão de guarda, quando um jornalista teve que quebrar a lei a fim de reunir informações que são importantes para o público. Em um Estado de Direito deve, naturalmente, existir a igualdade perante a lei e os jornalistas devem, portanto, como regra geral, ser punidos por violações da mesma forma que as outras pessoas. É, no entanto, difícil ver como esse princípio geral do Estado de Direito seria minado se a consideração pela liberdade de informação abrisse caminho para uma exceção no caso de violações necessárias da lei no curso do jornalismo investigativo em matérias de interesse público.

Em suma, a imprensa “cão de guarda" deve, em minha opinião, desfrutar de um privilégio condicional para violar a lei geral na busca de informação de interesse público sério, desde que a ação tomada tenha sido necessária para obter as informações e que não tenha envolvido nenhum (risco imediato de) dano ou prejuízo. Um privilégio/imunidade delimitado por tais condições estaria, em minha opinião, em consonância com a concepção "cão de guarda" da liberdade de imprensa. Nas circunstâncias descritas acima, processar o jornalista simplesmente para fazer valer um princípio de igualdade perante a lei parece

\footnotetext{
${ }^{64}$ Dammann c. Suíça, julgamento de 25 abr. 2006, Ap. no. 77551/01, parágrafo 56 (minha tradução do francês).
} 


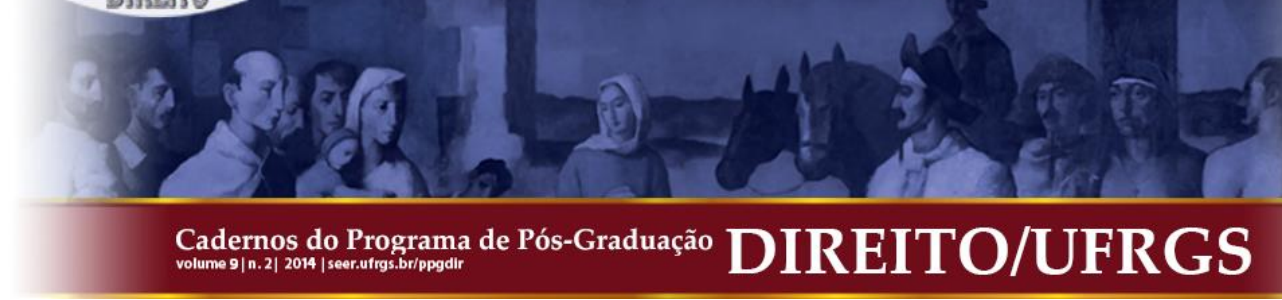

desproporcional, considerando o peso que em uma sociedade democrática deve ser atribuído à liberdade de imprensa no seu papel de "cão de guarda público". ${ }^{65}$

Embora, portanto, não deva ser impossível desenvolver diretrizes para delimitar a extensão dos privilégios/imunidades de imprensa por meio da ponderação, que certamente não é tarefa fácil, existem inúmeros contextos em que o problema pode surgir e uma cuidadosa ponderação caso a caso, assim, ainda pode ser necessária. Como em muitos outros campos dos direitos humanos, são necessárias soluções complexas para se chegar a resultados justos e equilibrados. Quanto ao alcance exato dos privilégios de imprensa, portanto, certo grau de insegurança jurídica é inevitável na busca por justiça material. Esse pode ser o preço a pagar por levar a sério o papel de "cão de guarda" da imprensa organizada e dos meios de comunicação de massa. Esse ponto é bem exemplificado pelo desenvolvimento da liberdade de imprensa no Direito dinamarquês.

\section{O DIREITO DINAMARQUÊS COMO EXEMPLO DO IMPACTO E DOS DILEMAS DA DOUTRINA DO "CÃO DE GUARDA PRIVILEGIADO"}

A tradição dinamarquesa, como a anglo-americana, parece repousar, essencialmente, em uma concepção de "fórum aberto" do significado da liberdade de imprensa. Essa concepção corresponde à redação do artigo 77 da Constituição da Dinamarca sobre a liberdade de expressão, que não prevê uma liberdade específica da imprensa ou um direito do público à informação. O artigo 77 prevê apenas que "qualquer pessoa deverá ter a liberdade para publicizar suas ideias pela impressão, escrita ou expressão" e que a censura ou qualquer outro tipo de censura prévia sobre a publicação é proibida. Assim, não existe no Direito dinamarquês tradição - seja em lei ou jurisprudência - de reconhecer em geral uma posição privilegiada da imprensa. De acordo com a tradição jurídica dinamarquesa, membros da imprensa e de outros meios de comunicação de massa devem ser tratados mais ou menos como qualquer outra pessoa. Como muito bem afirmou um juiz da Suprema Corte dinamarquesa em 1990, no contexto de comentar a respeito de um de muitos julgamentos dinamarqueses que condenaram jornalistas por violar a lei: "Não tem sido tradicionalmente

\footnotetext{
${ }^{65}$ Ver também RYTTER, Jens Elo. Når journalister bryder loven for at informere offentligheden. Juristen, Årg. 90, nr. 9, pp. 269-281, 2008.
} 


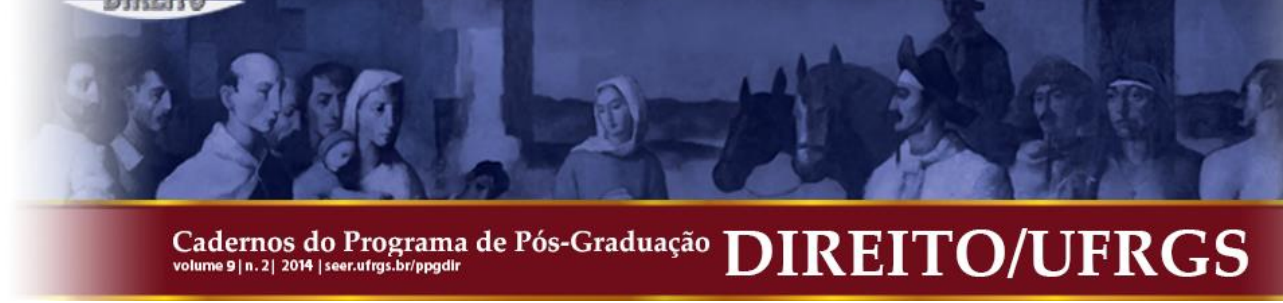

pressuposto que deve haver uma liberdade de expressão especialmente privilegiada para a imprensa." $" 66$

Inevitavelmente, no entanto, a concepção "cão de guarda" da liberdade de imprensa desenvolvida pelo Tribunal de Estrasburgo teria de influenciar o Direito dinamarquês devido à força vinculativa da CEDH em toda a Europa. Aparentemente, o caso Jersild de $1994,{ }^{67}$ que condenou a Dinamarca pela primeira vez por uma violação do artigo 10, foi a grande surpresa decisiva para os tribunais dinamarqueses. Pouco depois, os tribunais dinamarqueses passaram a parafrasear a concepção de liberdade de imprensa do Tribunal de Estrasburgo. No início, a linguagem foi um pouco cautelosa. Em uma decisão de 1994, o Supremo Tribunal dinamarquês considerou que "é importante que a mídia receba a oportunidade de informar o público a respeito de eventos que tratem de assuntos de interesse público e que são considerados como tendo [...] notícias e valor informativo". ${ }^{68}$ Posteriormente, porém, a concepção "cão de guarda" de Estrasburgo foi adotada por tribunais dinamarqueses e é agora rotineiramente referida nos casos de imprensa. O leading case que confirmou a concepção de Estrasburgo da liberdade de imprensa no Direito dinamarquês foi um julgamento da Suprema Corte de 1996:

\begin{abstract}
Ao ponderar a consideração pela liberdade de expressão e a consideração pela proteção contra insulto, o peso deve - nos casos relativos à expressão nos meios de comunicação - ser vinculado à necessidade de não definir restrições que impediriam a mídia de cumprir de forma razoável o seu papel de órgão de controle e informação do público ("cão de guarda público"). ${ }^{69}$
\end{abstract}

Essa nova "retórica de Estrasburgo" nos casos dinamarqueses de imprensa livre não é um mero faz de conta. Significa uma mudança real. A influência da concepção de liberdade de imprensa do Tribunal de Estrasburgo resultou em um aumento da proteção jurídica da imprensa no seu papel de fornecedora de informação e de cão de guarda público. A concepção modificada tem, por exemplo, reforçado a liberdade de imprensa como um intermediário do debate público, de modo que a imprensa, via de regra, não será mais condenada por

\footnotetext{
66 Jacques Hermann em Ugeskrift for Retsvaesen, København: G.E.C. Gad, 1990, afd. B, p. 25 (27). Ver também LAURIDSEN, Preben Stuer. Pressefrihed og personlighedsret. København: Gyldendal, 1988, p. 63 ss.; Jacques Hermann, Ugeskrift for Retsvasen, København: G.E.C. Gad, 1990, afd. B, p. 249 (251).

${ }^{67}$ Jersild c. Dinamarca, julgamento da Grande Câmara de 23 set. 1994, Ap. no ${ }^{\circ}$ 15890/89.

${ }^{68}$ Ugeskrift for Retsveesen, København: G.E.C. Gad, 1994, p. 988 (minha tradução).

69 Ugeskrift for Retsvaesen, København: G.E.C. Gad, 1997, p. 259/2 (minha tradução). Ver também, dentre outros, Ugeskrift for Retsvaesen, København: G.E.C. Gad, 1999, p. 122; 2002, p. 2398; 2003, p. 624; 2004 , p. $177 ; 2005$, p. 123 e 2008, p. 276/2.
} 


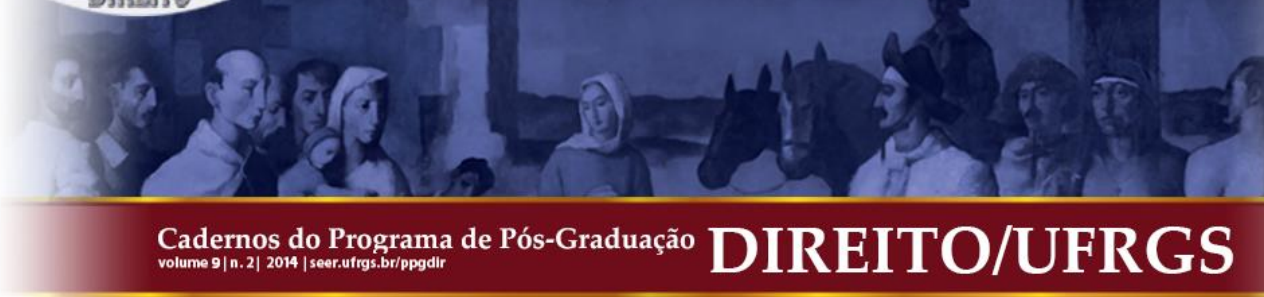

disseminar declarações puníveis feitas por terceiros. ${ }^{70}$ Mais importante, no entanto, a nova abordagem tem melhorado o acesso dos jornalistas à coleta de informações. Assim, o Tribunal Regional do Leste da Dinamarca, em 2000, observou "a tendência geral na legislação e na jurisprudência de respeitar e fortalecer a oportunidade para que os meios de comunicação ofereçam informação independente". ${ }^{71}$ Da mesma forma, um Tribunal Municipal dinamarquês recentemente referiu-se ao jornalismo "infiltrado" como sendo uma "função jornalística crucial em seu papel de cão de guarda público". ${ }^{72}$

\subsection{A Proteção das Fontes Jornalísticas e de Material}

Anteriormente, a proteção legislativa das fontes jornalísticas era bastante fraca e poderia ter precedência se a imprensa fosse considerada pelo Promotor de estar na posse de informações que pudessem ser relevantes para a investigação de crimes, mesmo menores, por exemplo, roubo. ${ }^{73} \mathrm{O}$ mesmo seria o caso de outros materiais jornalísticos; em um dos casos o Tribunal ordenou que um fotógrafo de jornal produzisse seu material de um incidente em que a propriedade privada foi danificada por manifestantes, já que o material poderia ser útil ao Promotor de Justiça. ${ }^{74}$

A jurisprudência de Estrasburgo tem contribuído para o reforço visível da proteção legislativa às fontes jornalísticas, o privilégio jornalístico, de acordo com a jurisprudência de Estrasburgo, tornando-se a regra clara com apenas exceções muito limitadas quando estritamente necessário para a investigação de crimes graves. ${ }^{75}$ No que diz respeito a determinar jornalistas a produzir seu filme e outro material para o Promotor de Justiça, o estado do Direito foi ajustado de forma semelhante em favor da imprensa, de modo que agora

\footnotetext{
${ }^{70}$ Ver da jurisprudência anterior Ugeskrift for Retsvaesen, København: G.E.C. Gad, 1989.399 H. À luz do julgamento de Estraburgo de Jersild c. Dinamarca essa posição agora mudou. Cf. e.g. Ugeskrift for Retsvaesen 1997.259/2 H (destruindo a condenação de um jornalista e seu editor pela publicação, no contexto de um artigo crítico a respeito de aconselhamento profissional no ramo imobiliário, as declarações insultuosas e puníveis dadas por uma pessoa privada a respeito de advogados específicos envolvidos nesse negócio) e Ugeskrift for Retsvasen, København: G.E.C. Gad, 2004.1773 H.

71 Ugeskrift for Retsvaesen, København: G.E.C. Gad, 2000, p. 1005/2 (rejeição de uma ordem judicial para produzir material jornalístico para ser usado como prova em investigação criminal).

72 Ugeskrift for Retsvaesen, København: G.E.C. Gad, 2009, p. 75 (no caso a ação jornalística realizada e protegida pelo tribunal era infiltrar-se em um ambiente criminoso organizado - a contratação de prostituição).

${ }^{73}$ Ver Ugeskrift for Retsvaesen, København: G.E.C. Gad, 1976, p. 973.

${ }^{74}$ Ver Ugeskrift for Retsvaesen, København: G.E.C. Gad, 1995, p. 402.

${ }^{75}$ Cf. Lei Judiciária dinamarquesa, § 172; ver também da jurisprudência a rejeição de uma ordem para depor, e.g. Ugeskrift for Retsvaesen, København: G.E.C. Gad, 2002, p. 1586.
} 


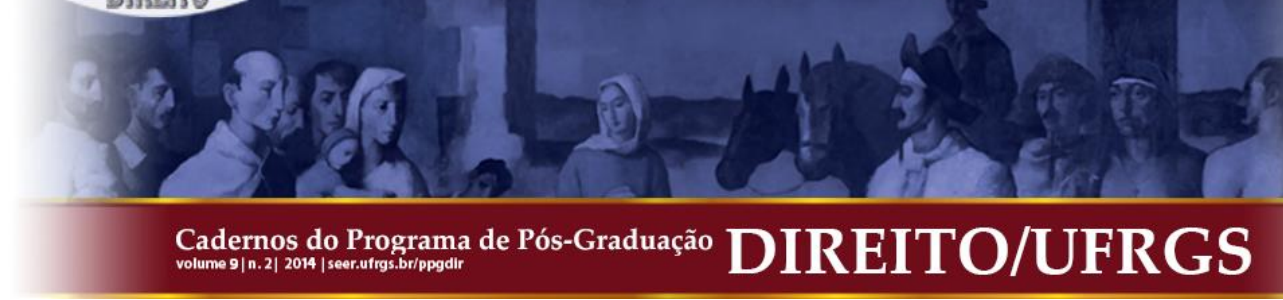

a regra é que tal ordem será na maioria das vezes rejeitada no interesse de uma imprensa independente capaz de coletar informações. ${ }^{76}$

\subsection{Invasão de Jornalistas para Relatar Manifestações}

Anteriormente, a imprensa era rotineiramente punida por invasão, mesmo que os jornalistas fossem apenas acompanhar manifestantes com o objetivo de informar ao público a respeito das manifestações e acontecimentos de interesse público. ${ }^{77}$ No entanto, em um caso de 1994, o Supremo Tribunal dinamarquês alterou a sua posição nesse tipo de caso, com referência explícita à jurisprudência de Estrasburgo a respeito da liberdade de imprensa; então agora os jornalistas podem muitas vezes esperar ser absolvidos mesmo que entrem em propriedade privada, desde que isso seja feito para cobrir eventos ou manifestações de interesse público. ${ }^{78}$

\subsection{Violação de Jornalistas à Lei no Processo de Investigação ("Infiltração")}

Quanto à questão mais controversa de jornalistas que violam a lei penal por conta própria como parte da realização de investigação ou jornalismo "infiltrado" para reunir informações não disponíveis de outra forma, não havia dúvida - e até muito recentemente não se tinha - na jurisprudência dinamarquesa de que eles deveriam ser punidos, independentemente de a violação ter sido talvez necessária para obter informações de interesse público substancial. Esses casos têm em sua maioria como causa o jornalismo "infiltrado", onde um jornalista fingiu ser outra pessoa a fim de obter informações, com a violação do direito penal consistindo em fingir ser um funcionário público ou em usar documentos de identificação falsificados. $\mathrm{O}$ artigo 10 da CEDH não foi referido em tais casos durante as décadas de 1980 e de 1990.

\footnotetext{
${ }^{76}$ Cf. e.g. Ugeskrift for Retsvaesen, København: G.E.C. Gad, 2000, p. 1005/2 e Ugeskrift for Retsvaesen, København: G.E.C. Gad, 2009, p. 75.

${ }^{77}$ Ver Ugeskrift for Retsvaesen, København: G.E.C. Gad, 1987, p. 934 e Ugeskrift for Retsvasen, København: G.E.C. Gad, 1987, p. 937.

${ }^{78}$ Ver Ugeskrift for Retsvaesen, København: G.E.C. Gad, 1994, p. 988 e Ugeskrift for Retsvasen, København: G.E.C. Gad, 1999, p. 1675; mas compare com Ugeskrift for Retsvaesen, København: G.E.C. Gad, 1998, p. 410.
} 


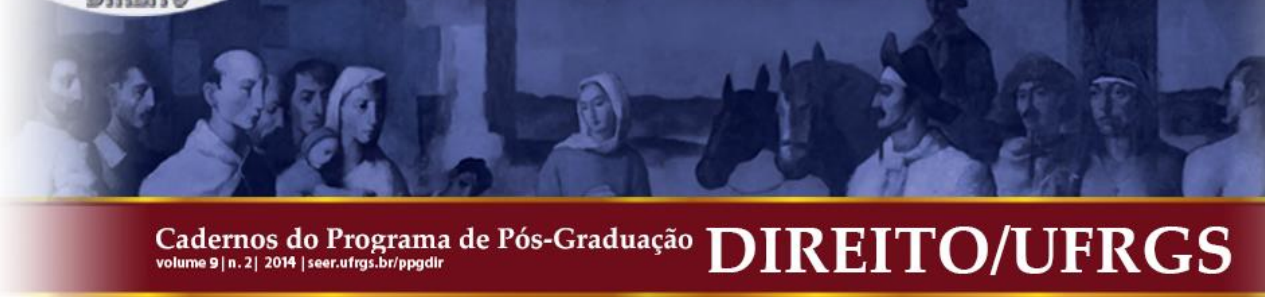

Em um caso de $1982,{ }^{79}$ dois jornalistas foram condenados por fingir ser policiais ao obter acesso a dados pessoais confidenciais das autoridades sociais. $\mathrm{O}$ objetivo foi estabelecer deficiências no tratamento de dados confidenciais pelas autoridades públicas - as autoridades não exigiram dos jornalistas documentação que demonstrasse que eram policiais. Os jornalistas foram condenados a uma multa.

Em um caso de $1989,{ }^{80}$ um jornalista apresentou uma certidão de nascimento falsa à polícia, em Copenhague, enquanto ele fingia ser um requerente de asilo iraniano. O objetivo era expor o tratamento de refugiados políticos pelas autoridades. Ele foi condenado a uma multa. O Supremo Tribunal considerou que, mesmo que o assunto fosse de interesse público, falsificação de documentos não pode ser tornada lícita por causa de reportagem de imprensa. Um juiz dinamarquês da Suprema Corte, ao comentar sobre a última decisão, explicou que:

\begin{abstract}
As considerações gerais subjacentes às disposições da lei penal sobre a falsificação de documentos tornaram, na visão do Supremo Tribunal, problemático se abrir aos métodos utilizados. Importância deve também ser atribuída ao fato de que o legislador, em geral, não proporcionou aos jornalistas qualquer posição privilegiada. Que alguém de vez em quando não possa realizar o que alguém com um fim jornalístico gostaria de realizar, sem o uso de meios ilícitos, não pode como uma regra de precedência legitimar a utilização de documentos falsificados. [...]. ${ }^{81}$
\end{abstract}

$\mathrm{Na}$ jurisprudência posterior, o artigo 10 da CEDH foi tomado em consideração na ponderação dos interesses em conflito, sem, contudo, afetar o resultado - a punição do jornalista.

Em um caso de $2000,{ }^{82}$ um jornalista da televisão dinamarquesa ganhou por meio da apresentação de um registo criminal, no qual o seu nome estava falsificado, uma posição como vendedor em uma grande companhia de seguros internacional. O objetivo era documentar que a companhia de seguros sistematicamente utilizava métodos condenáveis na venda de seguros de vida e de acidentes para partes privadas. O jornalista foi condenado a uma multa por falsificação de documentos. O Tribunal Regional considerou que o programa de televisão resultante dos métodos de infiltração do jornalista era de interesse público claro e tinha significativo valor jornalístico e informativo. Portanto, o interesse na aplicação da lei, de acordo com o Art. 10 (2) da CEDH, teve que ser sopesado contra o interesse na divulgação de

\footnotetext{
${ }^{79}$ Ugeskrift for Retsvaesen, København: G.E.C. Gad, 1982, p. 1005.

${ }^{80}$ Ugeskrift for Retsvaesen, København: G.E.C. Gad, 1990, p. 71.

${ }^{81}$ Jacques Hermann em Ugeskrift for Retsvasen, København: G.E.C. Gad, afd. B, p. 249 (251).

${ }^{82}$ Ugeskrift for Retsvaesen, København: G.E.C. Gad, 2001, p. 723.
} 


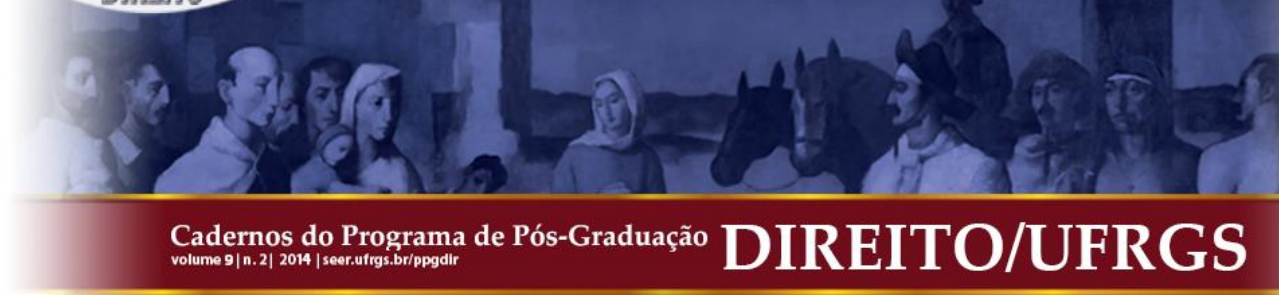

notícias. O Tribunal Regional não decidiu se - tal como reivindicado pelo conselho do jornalista, mas negado pela acusação - tinha sido necessário "infiltrar-se” para documentar métodos de vendas da companhia de seguros. Com referência ao fato de que a notícia foi coletada por iniciativa do jornalista e por meio de reportagens investigativas, o Tribunal Regional considerou que o interesse na função de controle da imprensa foi suplantado pelos interesses gerais por trás da criminalização da falsificação de documentos.

Em um caso de $2007,{ }^{83}$ dois jornalistas da televisão dinamarquesa compraram oito bombas de crisântemo para chamar atenção para as linhas ilegais de abastecimento de fogos de artifício, bem como para a facilidade de comprar nas ruas. As bombas foram imediatamente entregues à polícia, em Copenhague, com quem os jornalistas haviam discutido tal entrega, antes da compra. Definitivamente não foi sem perigo que os jornalistas, antes de entregar as bombas para a polícia, deixaram as bombas de crisântemo em seu carro, estacionado perto de um imóvel residencial. Em caso de ignição, as bombas compradas poderiam ter causado sérios danos a pessoas e bens dentro de um raio de 100 metros, de acordo com especialistas. Os jornalistas foram condenados por violação da lei de fogos de artifício e condenados a uma multa. O Tribunal Regional considerou que o assunto que os jornalistas queriam examinar tinha interesse público relevante e o programa que resultou da investigação dos jornalistas tinha significativo valor jornalístico e informativo. Portanto, o interesse na divulgação de notícias tinha de ser sopesado contra o caráter ilícito do ato, cf. art. 10 (2) da CEDH. O Tribunal não considerou, assim, se a violação tinha sido necessária para analisar um problema relevante para a sociedade. O Tribunal Regional registrou as preocupações de segurança consideráveis subjacentes às disposições da lei de fogos de artifício, bem como o fato de que os jornalistas, independentemente, tinham cometido um ato ilícito e, portanto, uma exceção à punição necessária exigia razões pesadas. Com base nisso, o Tribunal Regional não encontrou motivo de exceção de punição, nos termos do Art. 10 da CEDH.

Muito recentemente, os tribunais dinamarqueses estão aparentemente se abrindo para a possibilidade de isentar o jornalista de punição, alguns juízes até mesmo estando dispostos a absolver o jornalista, se a ação em violação da lei foi necessária para descobrir fatos de interesse público sério.

${ }^{83}$ Ugeskrift for Retsvaesen, København: G.E.C. Gad, 2007, p. 1673. 


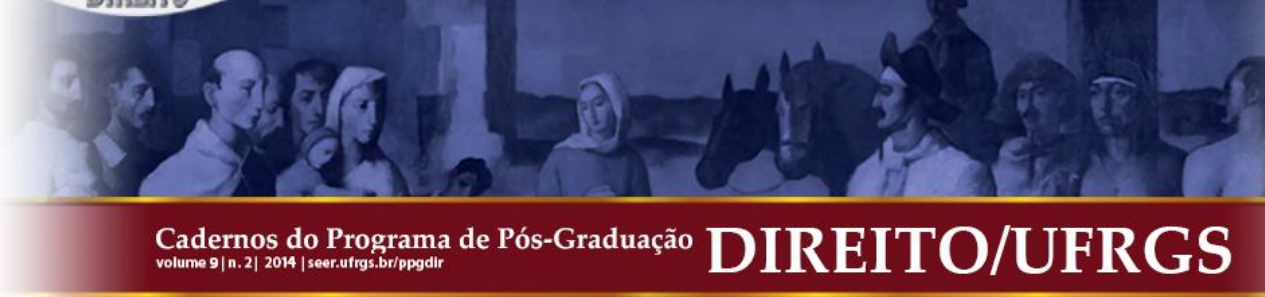

Em um caso do final de 2007,,$^{84}$ um jornalista de um jornal levou consigo uma faca de bife de um restaurante do salão de embarque do Aeroporto de Copenhague até o portão. O objetivo era mostrar que, apesar de um reforço na segurança após o 11 de setembro de 2001, houve uma falha de segurança no Aeroporto de Copenhague. Para documentar isso, o jornalista se permitiu ser fotografado com a faca no portão, mas não até que a maioria dos passageiros tivesse embarcado no avião. Imediatamente depois, a faca foi devolvida ao restaurante, que substituiu as facas de bifes por facas normais na mesma noite. O Supremo Tribunal, embora tenha condenado o jornalista, concedeu-lhe isenção da pena por referência, dentre outras coisas, à finalidade jornalística, mesmo que a maioria do Tribunal não tenha considerado a ação estritamente necessária para analisar um problema relevante; o Art. 10 da CEDH foi mencionado, mas não era visto como um obstáculo para a condenação, considerando-se que o jornalista tinha iniciado a violação por conta própria. Uma minoria dos juízes votou pela absolvição do jornalista, considerando a ação necessária para provar a brecha na segurança; eles não mencionaram o Art. 10 da CEDH. ${ }^{85}$

Em um caso de 2008, ${ }^{86}$ dois jornalistas de jornal tiveram, por meio da apresentação de cartões de seguro de saúde que pertenciam a outras pessoas e falsas declarações dadas à polícia, emitidos passaportes e carteiras de motorista com outros nomes. O objetivo era mostrar que era de fato possível obter tais documentos pessoais sem ter que documentar de forma eficiente a sua identidade e que havia, portanto, uma brecha na segurança das regras e procedimentos estatais para a emissão de passaportes e carteiras de motorista que poderiam ser - e eram - abusadas com intenção criminosa. Antes da ação, tanto o Ministério da Justiça como vários distritos policiais tinham rejeitado a sugestão dos jornalistas de que o abuso poderia ocorrer. Após isso, os jornalistas consideraram necessário testar a sua suspeita. Após a publicação da história, o Ministério da Justiça iniciou um endurecimento das regras de emissão de passaportes e carteiras de motorista, com base em artigos de jornal dos jornalistas. Os jornalistas foram posteriormente condenados por falsas declarações e falsificação de documentos. O Tribunal Regional constatou que as ações dos jornalistas estavam amparadas pelo art. 10 da CEDH e dizia respeito a uma questão de interesse público relevante. No entanto, o Tribunal não considerou a ação necessária, considerando que os jornalistas

\footnotetext{
${ }^{84}$ Ugeskrift for Retsvaesen, København: G.E.C. Gad, 2008, p. 671.

${ }^{85} \mathrm{Um}$ aspecto específico do caso foi que a disposição em causa da lei penal estava longe de ser clara; isso também teve um impacto sobre a decisão, mas não é claro a partir do raciocínio qual a importância.

${ }^{86}$ Ugeskrift for Retsvaesen, København: G.E.C. Gad, 2008, p. 1055.
} 


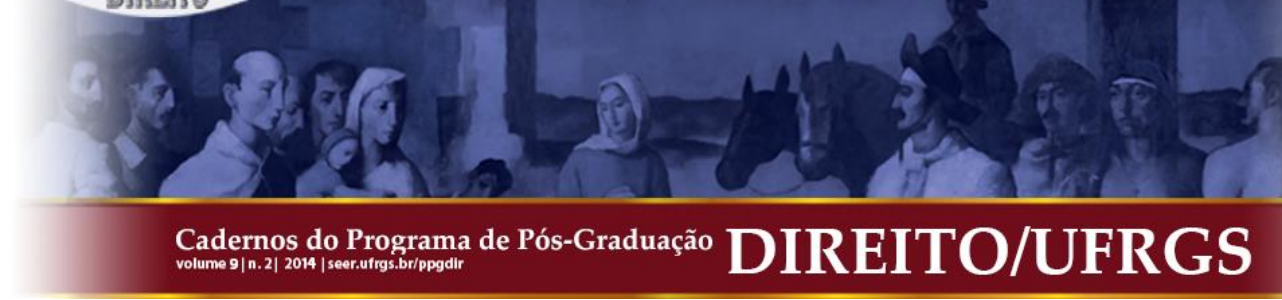

"poderiam ter chamado a atenção para a falha de segurança em um artigo de jornal sem cometer uma ilegalidade" (a avaliação do Tribunal sobre esse ponto é difícil de ser conciliada com os fatos). Por essa razão, dentre outras, o Tribunal Regional recusou uma isenção de punição e condenou os jornalistas a uma multa.

Em um caso do final de $2008,{ }^{87}$ uma jornalista e um fotógrafo da televisão dinamarquesa compraram uma arma de fogo e munições em violação à lei de armas, que proíbe a aquisição de armas sem licença. O objetivo da ação era provar como era fácil na Dinamarca comprar uma arma sem mostrar uma licença. Após a compra, a arma foi imediatamente guardada e no dia seguinte ela foi entregue à polícia. Essa foi uma questão de interesse público claro, e a crescente posse e uso de armas na sociedade dinamarquesa era uma questão política muito debatida. O Tribunal Regional parece ter reconhecido isso e também reconheceu que a compra ilegal de arma provavelmente tinha sido necessária para estabelecer de forma convincente o fato de que elas eram fáceis de obter. Embora se recusando a absolver os repórteres e seu editor, com referência ao artigo 10 da CEDH, o Tribunal entendeu que a consideração pela informação do público era de uma circunstância atenuante tamanha que os jornalistas deveriam ser isentos de punição.

Esses são casos delicados. Isenção de punição parece, em certa medida, uma solução salomônica para o dilema. No entanto, em minha opinião (como foi descrito na seção 5 acima), seria justificado, considerando o essencial papel de "cão de guarda" da imprensa, absolver o jornalista, em casos como o de 2008, relativo à segurança em torno da questão dos passaportes e carteiras de motorista: uma vez que o que foi descoberto pela ação foi de grande preocupação pública, a ação parece ter sido o único meio de estabelecer o problema de segurança, e nenhum dano concreto foi causado aos interesses privados ou públicos por causa da ação, a qual, em vez disso, gerou uma melhoria da segurança.

\section{CONSIDERAÇÕES FINAIS: QUAL O FUTURO DA IMPRENSA?}

Eu tentei mostrar que existem diferentes concepções do que "liberdade de imprensa", na verdade, significa - a concepção de "fórum aberto" e a concepção de "cão de guarda privilegiado". Embora optar pela concepção de "cão de guarda" dê à imprensa organizada

\footnotetext{
${ }^{87}$ Ugeskrift for Retsvaesen, København: G.E.C. Gad, 2009, p. 920.
} 


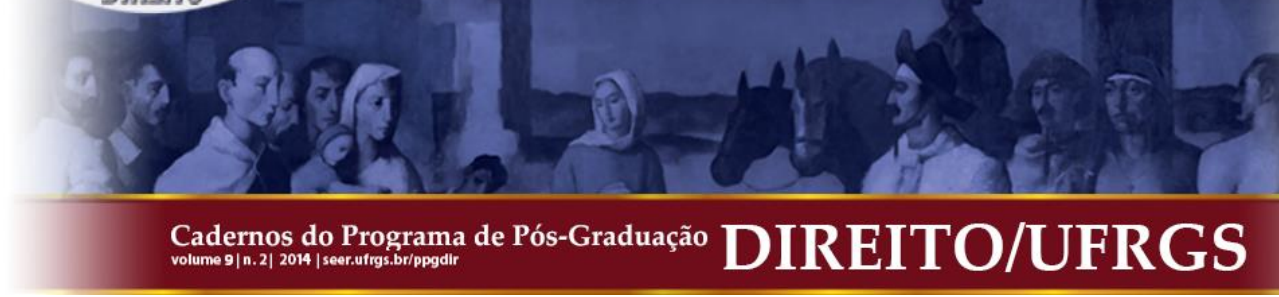

meios muito melhores de adquirir informações importantes e, assim, controlar as autoridades do que a concepção "fórum aberto", ela carrega consigo os dilemas de definir a imprensa privilegiada e, especialmente, delimitar os limites externos de privilégios especiais de imprensa.

No entanto, o desenvolvimento geral da sociedade demonstra que existem desafios mais profundos que podem ameaçar a própria concepção de uma imprensa "cão de guarda" no sentido tradicional.

Hoje, graças à Internet, o "panfletário solitário" dos velhos tempos pode se tornar um editor mundial por mérito próprio. À primeira vista, esse fato certamente desafia a abordagem institucional da liberdade de imprensa inerente à doutrina do "cão de guarda privilegiado". Ironicamente, o emergente anárquico cenário midiático - pós-moderno, pode-se dizer - se encaixaria muito melhor na visão tradicional da liberdade de imprensa como um "fórum aberto", sem privilégios especiais. ${ }^{88}$

A Internet, juntamente com outras tendências sociais, ainda ameaça a futura existência de meios de comunicação estabelecidos (established) e profissionais. Os meios de comunicação estabelecidos (established) em todo o mundo estão enfrentando uma crise sem precedentes, muitos lutando para sobreviver. Eles se encontram competindo não só com o fluxo constante de notícias e blogues da internet, mas também com produtos jornalísticos oferecidos gratuitamente. Ainda é incerto onde essa modificação vai acabar, mas um cenário possível é a imprensa tradicional chegando ao fim.

Da perspectiva de quem vê a imprensa como um "cão de guarda público" e até mesmo como um tipo de "quarto poder" na nossa democracia, um futuro sem uma imprensa organizada, profissional é, na verdade, um cenário sombrio. Ninguém, exceto a imprensa profissional pode realmente fazer o trabalho; blogueiros privados não terão a mesma responsabilidade e ética treinada como um jornalista profissional e, acima de tudo, não terão a mesma expertise e os recursos de coleta de informação e investigação a que dispõem os meios de comunicação de massa organizados. Nas palavras dramáticas de um experiente jornalista sueco de jornal:

\footnotetext{
${ }^{88}$ Cf. Paul Horwitz, "HORWITZ, Paul. Or of the [blog]. Excerpt reprinted. In: EPPS, Garrett (Ed.). The First Amendment. Freedom of the press: its constitutional history and the contemporary debate. Amherst: Prometheus Books, 2008, p. 328. Horwitz, no entanto, argumenta a favor da manutenção de uma imprensa privilegiada, porém esse termo deveria ser redefinido.
} 


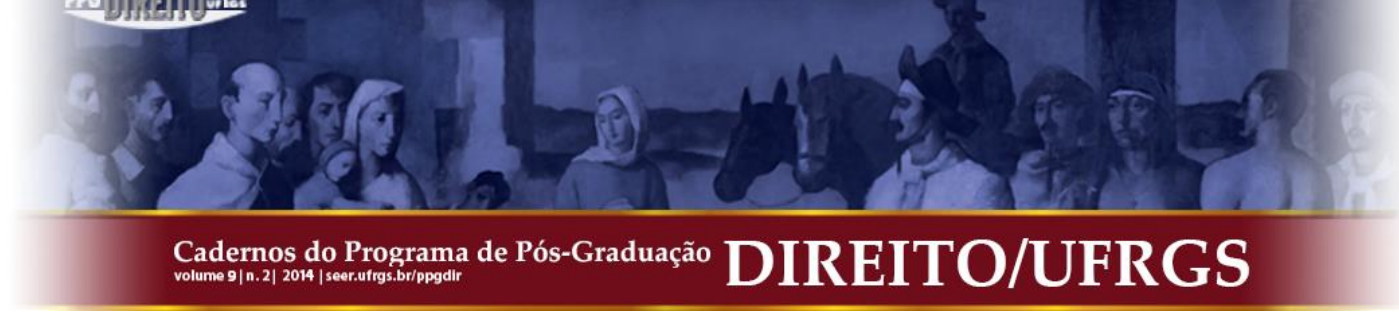

A Internet tem a ver, antes de tudo, com liberdade de expressão. A todo mundo é
dada a oportunidade de ser seu próprio professor, o que é oferecido raramente tem
profundidade e análise penetrante, como tal, é muito cara. [...] Em longo prazo, isso
pode ser devastador. Não há alternativa ao jornal sério. Até agora, não encontramos
nada para substituí-lo [...]. Se o som do jornal da manhã na caixa de correio
desaparece, então a conversa pública está em risco de se tornar muda ou ser
substituída pelo som de uma nova era: um ruído de fundo constante de nonsense, um
tagarelar eterno a serviço do entretenimento e do palavrear trivial, um som que,
paradoxalmente, está relacionado à marcha musical de ditaduras e a promessas
políticas vazias. ${ }^{89}$

Assim, o desenvolvimento tecnológico e a crise mundial da imprensa estabelecida (established) e de outros meios de comunicação de massa levanta a questão de saber se nós não podemos em breve ter de nos preocupar mais com a forma de preservar uma competente e independente imprensa "cão de guarda", indispensável para uma democracia informada, do que com a prudência e justificabilidade de conceder privilégios e imunidades especiais para essa imprensa.

\section{REFERÊNCIAS}

ANDERSON, David A. Freedom of the Press. Texas Law Review, v. 80, i. 3, pp. 429-530, 2002.

ANDERSON, David A. The Origins of the Press Clause. U.C.L.A. Law Review, v. 30, 455$541,1983$.

BARBER, Phil. A Brief History of Newspapers. Disponível em: < www.historicpages.com/nprhist.htm >. Acesso em 2010.

BARENDT, Eric. Freedom of Speech. $2^{\text {nd }}$ ed. Oxford: Oxford University press, 2008.

BEZANSON, Randall P. The Developing Law of Editorial Judgment. Nebraska Law Review, v. 78, pp. 754-857, 1999.

BLACKSTONE, William. Commentaries on the Laws of England. Chicago: Callaghan and Company, 1899 (1765-69).

89 SWARTZ, Richard. Pladdret efter dunsen. Dagens Nyheter, 3 okt 2009. Disponível em: < http://www.dn.se/ledare/kolumner/pladdret-efter-dunsen/ >. Acesso em 2010 (minha tradução do sueco). 


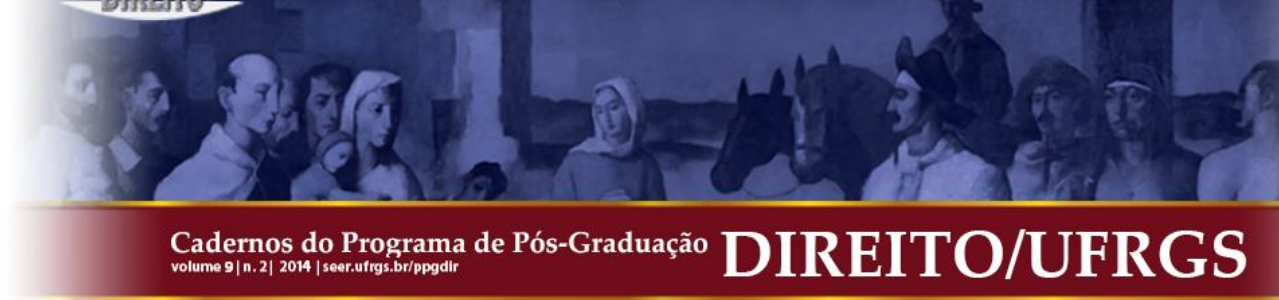

BUNDESVERFASSUNGSGERICHT (Hrsg.). Spiegel-Urteil. In: Entscheidungen des Bundesverfassungsgerichts. Bd. 20. Tübingen: Mohr, 1967, pp. 162-230.

HORWITZ, Paul. Or of the [blog]. Excerpt reprinted. In: EPPS, Garrett (Ed.). The First Amendment. Freedom of the press: its constitutional history and the contemporary debate. Amherst: Prometheus Books, 2008, pp. 322-338.

KJØLBRO, Jon Fridrik. Den Europaiske Menneskerettighedskonvention forpraktikere. 2. udgave. København: Jurist- og Økonomforbundets Forlag, 2007.

LANGE, David. The Speech and Press Clauses. U.C.L.A. Law Review, v. 23, pp. 77-119, 1975.

LAURIDSEN, Preben Stuer. Pressefrihed og personlighedsret. København: Gyldendal, 1988.

LEWIS, Anthony. Freedom for the Thought that we Hate (2007). Excerpt reprinted. In: KOHLER, D.; LEVINE, L. Media and the Law. Newark: LexisNexis, 2009, pp. 4-5.

MADISON, James. The Virginia Report of 1799. Reprinted. In: EPPS, Garrett (Ed.). The First Amendment. Freedom of the press: its constitutional history and the contemporary debate. Amherst: Prometheus Books, 2008, pp. 76-86.

MILTON, John. Areopagitica. Reprinted. Cambridge: Cambridge University Press, 1918.

NIMMER, Melville B. Introduction - Is Freedom of the Press a Redundancy: What does it add to Freedom of Speech? Hastings Law Journal, v. 26, pp. 639-658, 1975.

RYTTER, Jens Elo. Den Europaiske Menneskerettighedskonvention - og dansk ret. 2. udgave. København: Thomson, 2006.

RYTTER, Jens Elo. Når journalister bryder loven for at informere offentligheden. Juristen, Årg. 90, nr. 9, pp. 269-281, 2008. 
SCHAUMBURG-MULLER, Sten. Presseret. København: Jurist- og Økonomforbundets Forl, 2003.

STEWART, Potter. Or of the Press. Hastings Law Journal, v. 26, pp. 631-643, 1975.

SWARTZ, Richard. Pladdret efter dunsen. Dagens Nyheter, 3 okt 2009. Disponível em: < http://www.dn.se/ledare/kolumner/pladdret-efter-dunsen/ >. Acesso em 2010.

TOCQUEVILLE, Alexis de. Democracy in America. Chapter XI (1840). Reprinted. In: EPPS, Garrett (Ed.). The First Amendment. Freedom of the press: its constitutional history and the contemporary debate. Amherst: Prometheus Books, 2008, pp. 87-95.

Submissão: 30/12/2014 Aceito para Publicação: 30/12/2014 